\title{
The Use of Nanomaterials in Shaping the Properties of Cement Slurries Used in Drilling
}

\author{
Marcin Rzepka * and Miłosz Kędzierski@ \\ Division of Hydrocarbon Production Engineering, Oil and Gas Institute-National Research Institute, \\ ul. Lubicz 25A, 31-503 Krakow, Poland; kedzierski@inig.pl \\ * Correspondence: rzepka@inig.pl
}

Received: 14 April 2020; Accepted: 12 June 2020; Published: 16 June 2020

\begin{abstract}
For several decades, constant research has been performed in the world in order to obtain more durable, tighter, or less environmentally harmful binding materials which could be used to seal casing strings in boreholes. There is an increasing search for innovative solutions allowing the production of the highest possible class of binding cements. Since the beginning of the 21st century, one thing which has become synonymous with development is nanotechnology—a dynamically growing branch of science involving both the design, production, and testing of structures with the size of billionths of a metre. Among other things, a set cement stone is made of the grains of hydrated calcium silicates and calcium aluminates, between which there are pore spaces. Fine grains of nanoparticles can successfully settle inside these spaces, causing a decrease in the porosity and permeability of cement matrix. The paper presents the results of laboratory tests performed for formulas of cement slurries containing between $0.5 \%$ and $1 \%$ of nanosilica, between $1 \%$ and $3 \%$ of nanosized alumina and approximately $0.1 \%$ of carbon nanotubes. The resulting slurries had a density of approximately $1830-1920 \mathrm{~kg} / \mathrm{m}^{3}$ and zero water settling. The thickening times of slurries were selected in accordance with the given geological and technical conditions. Early compressive strength amounting to $3.5 \mathrm{MPa}$ (based on a test using an ultrasound cement analyser) was achieved by slurries after times between approximately 7 and $14 \mathrm{~h}$. Upon setting of samples, cement stones produced from slurries featured a very low share of capillary pores. After 28 days of hydration, the compressive strength of the resulting cement stones took on very high values, reaching even up to $50 \mathrm{MPa}$. Photographs of cement stones containing nanomaterials (taken by means of scanning microscopy) are a confirmation of the exceptionally compact microstructure of the resulting samples.
\end{abstract}

Keywords: wellbore stability; nanosilica; nanosized alumina; carbon nanotubes; cement slurry; set cement; mechanical strength

\section{Introduction}

Nanotechnology is listed as a field of science focused among other things on testing, designing and producing components of very small sizes. These components have grain sizes of several dozen nanometres, which allows them to constitute a basis for products with specific technological properties. The possibilities of using the so-called nanomaterials, i.e., materials with particle dimensions, pore dimensions, or film thickness ranging between 1 and $100 \mathrm{~nm}$, are very wide, and due to the intense development of science in this field, the early decades of the 21st century have been described as the beginning of the era of nanotechnology.

Over recent years, the development of technologies for perfecting cement compositions proceeded primarily via the use of materials of decreasing sizes [1,2]. Reduction in the grain sizes of the used components took place during specific stages of the development and production of cement, e.g., the grain diameter of ground sand amounts to approximately $0.04-0.05 \mathrm{~mm}$ (i.e., approximately 
40,000-50,000 nm), with 150-200 nm for silica dust, while for nanosilica, nanosized alumina, or carbon nanotubes (the smallest dimension) it amounts to approximately $10-20 \mathrm{~nm}$. Therefore, the use of nanosilica, nanosized alumina or carbon nanotubes in the composition of cement slurry is a considerable step in the technological development of this branch of industry [3-6]. Nanoparticles (including $\mathrm{n}-\mathrm{SiO}_{2}$ and $\mathrm{n}-\mathrm{Al}_{2} \mathrm{O}_{3}$ or carbon nanotubes) fill empty spaces between cement grains, resulting in the closure of pore channels in the cement matrix [7-9]. Moreover, properly dispersed nanoparticles cause the hydration of cement slurry to accelerate and favour the generation of small crystals and small homogeneous aggregates of the C-S-H phase-the main building block of cement matrix-responsible for one of the most important parameters of the slurry, which is its mechanical strength. In addition, nanoparticles participate in pozzolanic reactions or accelerate them, due to which some of the chemically unstable portlandite $\mathrm{Ca}(\mathrm{OH})_{2}$ is "used up" in cement during setting, and "additional" gel of the C-S-H phase is created, reinforcing the skeleton of cement matrix $[9,10]$. Further positive features of nanoparticles include improving the structure of contact with cement grains, which results in stronger binding and limiting the number of possible fractures.

Cement products containing nanocomponents are characterised by being harder, stronger, or having much smoother surfaces compared to products made of conventional cements. Even small amounts of nanomaterials used as additions to cement slurry can cause thickening of the crystalline structure of cement formula, reduce the size of pores and their number, and thus noticeably improve the technological parameters of the resulting product. This is why a number of scientific centres in the world have begun research on the use of nanotechnology, e.g., in cementing operations performed when sealing petroleum wells [3,11,12].

Very often, high temperatures and pressures prevalent in a borehole require the use of particularly resistant cement slurries, containing technologically advanced additives, helping achieve proper isolation between zones. Due to the frequent adoption of numerous solutions in drilling, which have been used, e.g., in construction practice, it can be presumed that in the coming years nanomaterials will be found useful when designing cement slurries for sealing the casing strings of boreholes.

In the literature $[13,14]$, there are provided examples of using nanosilica or nanosized alumina, as well as carbon nanotubes, which considerably influence an increase in the compressive strength, along with the durability and tightness of the cement matrix. Even at temperatures of $25^{\circ} \mathrm{C}$ cement samples with nano-SiO${ }_{2}$ and nano- $\mathrm{Al}_{2} \mathrm{O}_{3}$ achieved high compressive strength, as high as $30 \mathrm{MPa}$ after 2 days and almost $50 \mathrm{MPa}$ after 28 days [15]. Set cement slurries with nanosilica had low porosity and their pore distribution were characterized by a small number of pores with diameters greater than $100 \mathrm{~nm}$, in the range 1.3-2.5\%, which prove their compact structure and low permeability. Moreover they exhibited low gas permeability [16]. The experimental results showed that the compressive and flexural strengths measured at the 7th day and 28th day of the cement mortars mixed with the nano-particles were higher than that of a plain cement mortar [7]. Porosity and permeability significantly were declined by $33.3 \%$ and $99 \%$, respectively, and compressive strength grew from 1486 psi to 3801 psi [17]. Research indicates that, apart from improving the mechanical properties of cement stones, the addition of nanosilica to a certain degree also influences a decrease in the filtration of liquid cement slurry.

\subsection{Nanosilica $\left(n-\mathrm{SiO}_{2}\right)$ in Cement Slurry Technology}

The compressive and flexural strength of cement slurry with an addition of $\mathrm{n}-\mathrm{SiO}_{2}$ proves to be higher than the strength of conventional cement slurry with a similar water-cement ratio [17-19]. Apart from an increase in strength, the addition of nanoparticles also has a positive impact on the distribution of stresses in the set cement stone. Cement is known to be a porous material with a pore size from several nanometres to several micrometres. These pores are filled primarily with an alkaline solution of calcium dissolved in water. This is why environmental conditions characterised by lower $\mathrm{pH}$ disrupt the balance and are disadvantageous for concrete. Not only does research conducted in scientific centres for samples in which nanosilica has been used as an addition to the slurry indicate its 
impact on an increase in the average length of the C-S-H gel chain, but also the fact that it causes the generation of a high stiffness phase of this gel, replacing its low stiffness phase, which considerably contributes to an increase in the strength of the created cement stone.

Cement stone matrix is known to consist mainly of the grains of hydrated gel of calcium silicates and the crystals of hydrated products of hydration, between which there are nanopores and capillary pores. It is an ideal place for nanoparticles to thicken the structure of cement slurry by filling voids present in the matrix. However, due to their high surface energy, nanoparticles can be easily combined into aggregates, causing considerable difficulties in their dispersion (especially for larger amounts). In this case, the creation of aggregates of nanoparticles causes the generation of empty spaces which can affect the weakening of the mechanical properties of cement slurries. To prevent this, it is necessary to properly homogenise batched water containing nanocomponents, e.g., by means of sonicators or high-speed agitators [20]. The most preferable strength parameters for cement stones modified with carbon nanotubes (CNTs) were achieved by dispersing CNTs using sonication [21-24]. Ultrasound sonicators convert mains voltage into mechanical vibrations. These mechanical vibrations are transferred into a liquid by a probe, creating a pressure wave. This action causes the generation and rapid collapse of microscopic bubbles. This phenomenon, defined as cavitation, creates millions of shock waves, increasing the temperature of the liquid [25]. The cavitational collapse lasts only several microseconds. Although the amount of energy released by each individual bubble is low, the cumulative effect causes the release of extremely high energy levels, causing the dispersion of objects and surfaces inside the cavitation area.

\subsection{Nanosized Alumina $\left(n-\mathrm{Al}_{2} \mathrm{O}_{3}\right)$ in Cement Slurry Technology}

The use of nanosized alumina $\left(\mathrm{n}-\mathrm{Al}_{2} \mathrm{O}_{3}\right)$ in cement slurries has been described by the authors of $[8,26]$. After the performance of laboratory analyses, they pointed out the great advantages of such slurries, paying particular attention to an improvement in mechanical strength, the compressive strength of composite increased by $30 \%$ at 7 days [8]. The authors have also noticed that particles of nanosized alumina did not have a clear impact on the density of cement slurries, and after being added to the formula they caused an acceleration of its binding time. After using nanosized alumina, the authors also observed an increase in the viscosity and yield point of slurry, as well as a decrease in water settling (free water) in the slurry (which constitutes a particular advantage when sealing boreholes). In addition, $\mathrm{Al}_{2} \mathrm{O}_{3}$ nanoparticles are able to act as nanofillers and recover the pore structure of the specimens by decreasing harmful pores [9]. Studies performed by the abovementioned authors involved mainly tests performed under conditions defined by the API quality standard, without taking into account in a broader scope the introduction of additives and admixtures necessary to prepare a proper cement formula.

\subsection{Carbon Nanotubes (CNTs) in Cement Slurry Technology}

Carbon nanotubes (CNTs) have excellent mechanical properties, and this is why in combination with ordinary Portland cement they can create nanocomposites harder than traditional reinforcing materials (e.g., glass fibres or carbon fibres) [27]. The addition of CNTs leads to an increase in the number of hydrate crystals generated in cement slurry and a change in their morphological structure [10]. The research performed so far proves that the addition of carbon nanotubes can increase the strength of cement stone $[28,29]$. It was concluded that a small amount of effectively dispersed CNTs can increase flexural strength considerably. The addition of short, multi-walled CNTs in an amount of $0.08 \%$ caused an increase in flexural strength by 35\% and an increase in Young's modulus [21,30]. Even better results were produced for compressive strength. The addition of CNTs in an amount of $1.0 \%$ in relation to the mass of dry cement led to an increase in compressive strength to a value of $51.8 \mathrm{MPa}$ after 28 days of hydration $[8,10,31]$. Li et al. [32,33] obtained a $25 \%$ increase in flexural strength and a $19 \%$ increase in compressive strength. Cwirzen et al. [34] reported that the 50\% increase in compressive strength of cement slurry specimens using multi-walled carbon nanotubes (MWCNTs) that were $0.045-0.15 \%$ 
of the cement weight. Improved mechanical properties of cement slurry have been achieved up on addition of $0.1 \%$ CNTs [35,36]. Paula et al. [37] reported that an average $15 \%$ gain was achieved in tensile strength at ages of $48 \mathrm{~h}$ and 7 days for $0.1 \%$ CNTs bwoc. Other tests concluded that the addition of nanotubes to cement composites caused a drop in compressive strength [38]. A decline in the mechanical properties has been reached by the addition of $0.15 \%$ CNTs [35]. Modification of cement slurry by means of the addition of CNTs in an amount of $0.5 \%$ (bwoc) caused a drop in compressive strength by approximately $80 \%$ [20]. The increase in the additive concentration causes reduced compressive strength because of unsuitable dispersion of nanoparticles in the cement stone matrix [39]. The varying impact of CNT additions on the mechanical properties of cement materials can be probably explained by various choices regarding the type and number of CNTs and methods for dispersing nanotubes.

\subsection{The Mechanism of Improving the Degree of Compactness of Cement Matrix Microstructure}

Generally, the mechanism of improving the degree of compactness of cement matrix microstructure and an increase in the strength of cement stones can be presented as follows. Small numbers of nanoparticles introduced into slurry are uniformly dispersed in it. Cement hydration products begin their deposition on nanoparticles due to their high surface energy. During the hydration process, generation of conglomerates containing nanoparticles as nuclei occurs in the slurry. Nanoparticles dispersed in cement slurry will additionally support and accelerate the hydration of cement due to their high reactivity. By achieving uniform dispersion of nanoparticles, it is possible to obtain a microstructure with uniformly dispersed conglomerates [1,40,41].

The following possible ways of increasing the strength of cement stone can be identified:

- nanoparticles act as nuclei/nucleons strongly bound with cement hydrates, thus favouring the hydration of cement;

- nanoparticles can prevent the growth of large crystals, such as portlandite- $\mathrm{Ca}(\mathrm{OH})_{2}$;

- nanoparticles and small agglomerates can fill pores in cement stone (similar to silica dust), thus increasing its mechanical strength.

It is assumed that these mechanisms play a leading role in improving the compressive strength of samples of set cement slurries.

During the preparation of cement slurries containing an addition of nanoparticles, it is extremely important to select a proper water-cement ratio w/c [7]. Because of the w/c ratio being too low, the hydration of cement grains will be incomplete and their considerable part can remain unhydrated. The nanocomponents will then have limited possibilities of fitting into porous spaces. Such a situation can cause the generation of agglomerates, which cause a considerable increase in viscosity of the slurry. On the other hand, with the w/c ratio being too high, the porosity of cement matrix will increase. Some of the water will remain unused and large capillary pores will be created in spaces between grains, which will not be filled with nanoparticles.

\subsection{The Purpose of the Study}

The cited literature presents the recipes of cement slurries with a limited number of additives modifying the properties of the slurries (e.g., only a liquefying agent was used). These slurries cannot be used in borehole conditions. The Oil and Gas Institute-National Research Institute also attempted the development of innovative cement slurries enriched by an addition of nanoparticles of silica $\left(\mathrm{n}-\mathrm{SiO}_{2}\right)$, nanosized alumina $\left(\mathrm{n}-\mathrm{Al}_{2} \mathrm{O}_{3}\right)$ and carbon nanotubes $(\mathrm{CNTs})$, which in the coming years can be used in the process of sealing the casing strings of boreholes at depths from several hundred to approximately two thousand metres, where bottom temperatures are approximately $25-60^{\circ} \mathrm{C}[15-18,42,43]$. Cement slurries presented in the article contain materials commonly used by cementing services for sealing casing strings (liquefying additive, anti-filtration additive, defoamer, 
setting time additive). The purpose of the study was to propose innovative formulations for cement slurries with nanocomponents, with improved technological properties for industrial applications.

\section{Materials and Methods}

\subsection{Materials}

CEM I 42.5R Portland cement and Class G drilling cement was used to make the slurries. Table 1 shows the chemical characteristic of the cement used in these studies.

Table 1. Chemical characterization of Class G drilling cement and Portland cement CEM I 42,5R.

\begin{tabular}{ccc}
\hline Chemical Characterization & \multicolumn{3}{c}{ Sample (\%) } \\
& Portland cement CEM I 42,5 R & $\begin{array}{c}\text { Class G } \\
\text { drilling cement }\end{array}$ \\
\hline $\mathrm{SiO}_{2}$ & 19.88 & 21.64 \\
$\mathrm{Fe}_{2} \mathrm{O}_{3}$ & 2.64 & 4.90 \\
$\mathrm{Al}_{2} \mathrm{O}_{3}$ & 4.94 & 4.19 \\
$\mathrm{CaO}$ & 63.33 & 64.11 \\
$\mathrm{MgO}$ & 1.06 & 0.84 \\
$\mathrm{SO}_{3}$ & 3.03 & 2.34 \\
$\mathrm{Na}_{2} \mathrm{O}$ & 0.13 & 0.52 \\
$\mathrm{~K}_{2} \mathrm{O}$ & 0.95 & - \\
Loss on ignition & 4.04 & 0.72 \\
\hline
\end{tabular}

The materials used in the tests are commonly used by European cementing services for sealing casing strings. Table 2 provides basic information on the measure taken during laboratory tests.

Table 2. Materials used in composition of the oil-well cement slurries.

\begin{tabular}{|c|c|}
\hline Class & Material \\
\hline Cement & Class G drilling cement \\
\hline Cement & Portland cement CEM I 42,5R \\
\hline Nanosilica n-SiO 2 & Grain diameter of approximately $20-30 \mathrm{~nm}$ (powdered) \\
\hline Nanosized alumina $n-\mathrm{Al}_{2} \mathrm{O}_{3}$ & Grain diameter of approximately $20-30 \mathrm{~nm}$ (powdered) \\
\hline Multi-walled carbon nanotubes (MWCNTs) & $\begin{array}{l}\text { External diameter of approximately } 10-20 \mathrm{~nm} \text { and length of } \\
\qquad 10-30 \mu \mathrm{m} \text { (in the form of black powder) }\end{array}$ \\
\hline Defoamer & Esters of unsaturated aliphatic acids \\
\hline Setting stimulant & $\mathrm{CaCl}_{2}$ \\
\hline Liquefying additive (plasticiser) & $\begin{array}{l}\text { Modified sodium salt of sulphonated } \\
\text { naphthalene-formaldehyde polycondensate }\end{array}$ \\
\hline Anti-filtration additive & Modified carboxymethylcellulose derivates \\
\hline Setting time retardant & Lignosulphonate \\
\hline Swelling additive & Organic and inorganic lime chemical compounds \\
\hline Water & Tap water \\
\hline
\end{tabular}

The tests used powdered n-SiO${ }_{2}$. Silicon Oxide Nanoparticles/Nanopowder $\left(\mathrm{SiO}_{2}\right.$, diameter 20-30 nm: 99.5\%), with a specific surface area SSA of: 200-600 $\mathrm{m}^{2} / \mathrm{g}$ (Figure 1a,b).

With respect to nanosized alumina $\mathrm{n}-\mathrm{Al}_{2} \mathrm{O}_{3}$, Aluminium Oxide Nanopowder, a product was used in which $99 \%$ of particles had diameters of approximately $20-30 \mathrm{~nm}$. Figure $2 \mathrm{a}, \mathrm{b}$ present $\mathrm{n}-\mathrm{Al}_{2} \mathrm{O}_{3}$ used during the tests and its structure.

The tests used multi-walled carbon nanotubes (MWCNTs) with an external diameter of 10-20 nm and a length of 10-30 $\mu \mathrm{m}$, and with purity above $95 \%$, with a specific surface area of: $233 \mathrm{~m}^{2} / \mathrm{g}$ and bulk density $0.22 \mathrm{~g} / \mathrm{cm}^{3}$ Figure $3 \mathrm{a}, \mathrm{b}$ present MWCNTs used during the tests. 


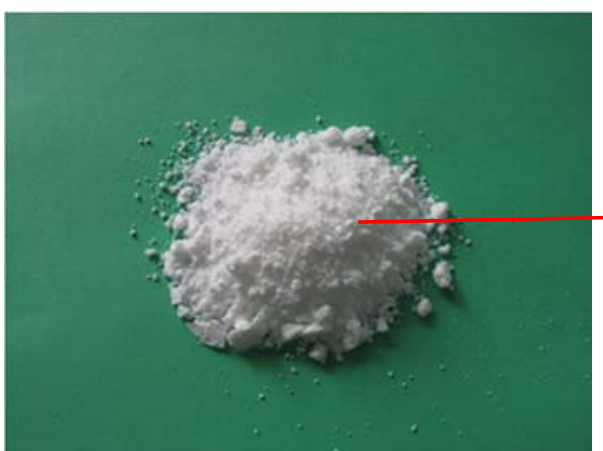

(a)

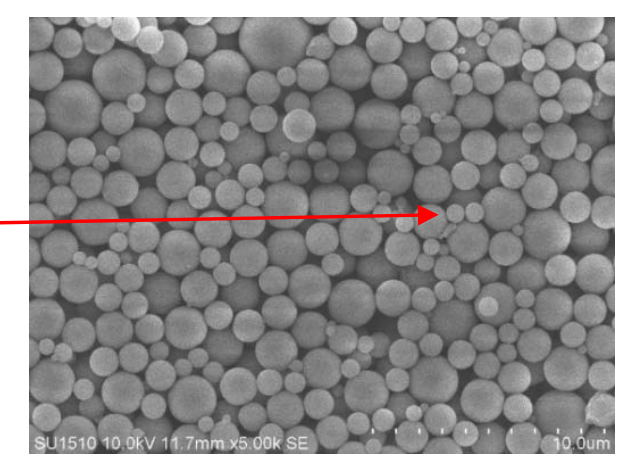

(b)

Figure 1. (a): nanosilica $\mathrm{n}-\mathrm{SiO}_{2}$ with a grain diameter of approximately 20-30 nm (powdered) used in laboratory tests. (b): microstructure of this nanosilica (photograph taken under a scanning microscope) [44]. The arrow marks a single particle of $\mathrm{n}-\mathrm{SiO}_{2}$.

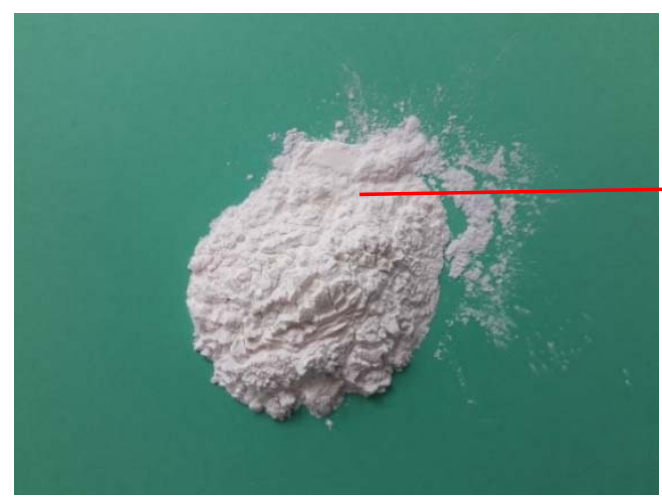

(a)

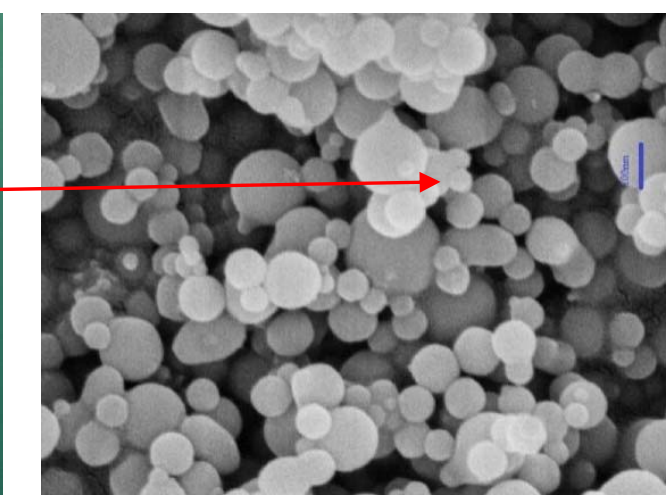

(b)

Figure 2. (a): nanosized alumina $\left(\mathrm{n}-\mathrm{Al}_{2} \mathrm{O}_{3}\right)$ with a grain diameter of approximately $20-30 \mathrm{~nm}$ (powdered) used in laboratory tests. (b): microstructure of this nanosized alumina (photograph taken under a scanning microscope) [45]. The arrow marks a single particle of n- $\mathrm{Al}_{2} \mathrm{O}_{3}$.

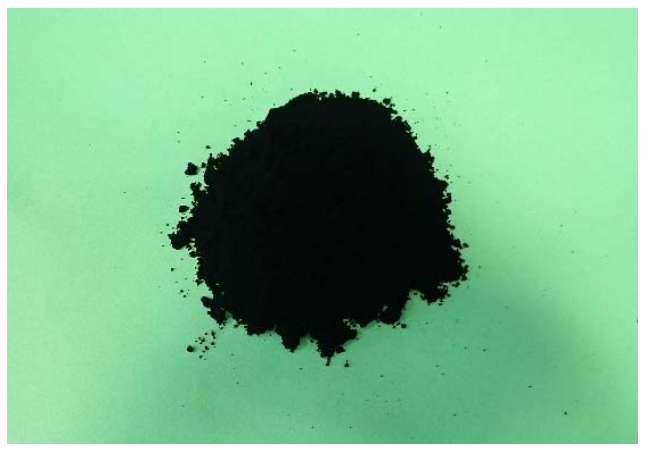

(a)

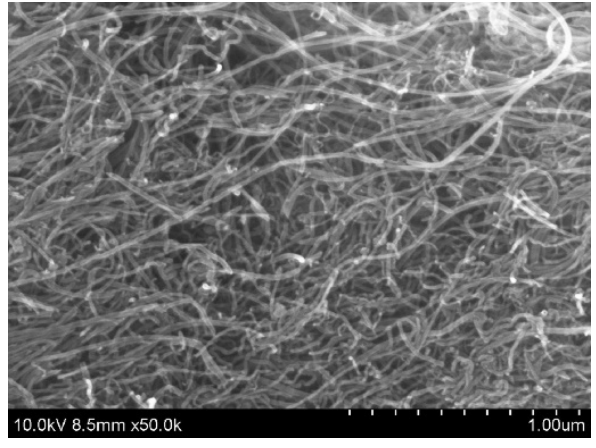

(b)

Figure 3. (a): multi-walled carbon nanotubes (MWCNTs) with an external diameter of approximately 10-20 nm and length of 10-30 $\mu \mathrm{m}$ (in the form of black powder) used in laboratory tests. (b): microstructure of carbon nanotubes (picture taken under a transmission electron microscope) [46]. 


\subsection{Experimental Procedures and Slurry Preparation}

The laboratory tests and examinations of cement slurries containing nanocomponents were performed in the Oil and Gas Institute-National Research Institute (INiG-PIB) according to the following standards: Oil and gas industry-Cements and materials for well cementing-Part 1: Specification (ISO 10426-1:2009) and Oil and gas industry-Cements and materials for well cementing-Part 2: Testing of well cements (ISO 10426-2:2003) [47,48].

Slurries were prepared at ambient temperature. The increase in compressive strength and thickening time was studied in conditions similar to those prevailing in the wells. All nanomaterials were added to batched water and dispersed by means of the Sonics VC505 sonicator (using a homogenisation time of $3 \mathrm{~min}$ ). Under laboratory conditions, $200 \mathrm{~mL}$ of mixing water was measured and the appropriate amount of nanocomponents were added to it. To the nanocomponent suspension prepared as described, the remaining amount of mixing water was added to obtain the required w/c ratio and then particular additives were introduced in the order provided in the tables presenting the compositions of the tested cement slurries. After thorough mixing of all additives and admixtures, a suitable type of cement was added and homogenised for $30 \mathrm{~min}$ at $1800 \mathrm{rpm}$.

In field conditions (at the drill site), it is possible to use a dispersed suspension of nanomaterials delivered in containers.

Screening tests were carried out for different $\mathrm{w} / \mathrm{c}$ ratios. In case of $\mathrm{w} / \mathrm{c}$ higher than 0.5 , clear sedimentation was observed (cement grains settling and water phase formation at the top of specimens). $\mathrm{W} / \mathrm{c}$ ratios below 0.44 caused a very clear increase in the density of the slurry (plastic viscosities were very high). Therefore, in all the tested slurries, the w/c ratio was selected individually based on the amount of nanomaterials used. So: the $\mathrm{w} / \mathrm{c}$ ratio was between 0.44 and 0.49 . The dosage of admixtures to slurries was based on safety data sheets of particular chemical substances. Typical amounts of chemical substances were used. The main criterion in determining the compositions was to obtain optimal technological parameters of the final formulation by the slurries. Attempts have been made to prepare cement slurries without free water, with a typical density of about $1.80-1.95 \mathrm{~g} / \mathrm{cm}^{3}$. Attention was paid to the rheological parameters in order to enable efficient cementing of casing strings. Thickening times have been adjusted in such a way as to ensure safe pumping of the cement slurry into the annular space in the wellbore, while maintaining a safety margin (in case of any unforeseen situations). The thickening times were therefore selected according to the temperature at the bottom of the wellbore, which depends to a large extent on the final depth to which the wellbore is drilled.

In the course of the task, a number of parameters of cement slurries were determined, namely:

\subsubsection{Slurry Density}

Determination of the cement slurry density-performed using a Baroid mud balance at $22{ }^{\circ} \mathrm{C}$ and atmospheric pressure. The cement slurry was poured into the weighing cup, covered with a lid, and the excess slurry flowing out through the opening was rinsed and the cup was wiped dry. The density reading was made at the horizontal position of the graduated arm.

\subsubsection{Slurry Filtration}

Filtration measurement was carried out using a filter press. The cement slurry was poured into a vessel in which it was mixed during the increase in pressure and temperature. After the mixing and heating cycle was completed, the vessel was turned without transferring the slurry. During the test, the slurry was subjected to a differential pressure of $7 \mathrm{MPa}$. The filtrate was collected in the measuring cylinder for $30 \mathrm{~min}$, and the slurry filtration was calculated based on its quantity.

\subsubsection{Rheological Properties}

Rheological properties were measured using a viscometer. The viscometer is used to directly determine the relationship between the shear rate of a liquid and the occurring shear stress, enabling the 
calculation of plastic viscosity, apparent viscosity, and yield stress, and the measurement of structural strength. After mixing, the tested cement slurry sample was poured into a measuring vessel, then a rotating cylinder was submerged and readings were taken at specific speeds. Plastic viscosity, yield stress and structural strength were calculated from the formulas given in PN-EN ISO 10426-2:2003 [48].

\subsubsection{Thickening Time}

A pressurised consistometer was used to determine the thickening time. The prepared cement slurry was placed in the cup of the consistometer, according to the device's manual. A chart of temperature and consistency changes of the cement slurry was recorded. The thickening start time was determined when the slurry reached the consistency of $30 \mathrm{Bc}$. The thickening end time (thickening time) was determined when the slurry reached the consistency of $100 \mathrm{Bc}$.

\subsubsection{Free Water}

Determination of free water-consisted in measuring the volume of the water solution accumulating above the surface of the slurry. The measurement was performed at $22{ }^{\circ} \mathrm{C} .500 \mathrm{~cm}^{3}$ of cement slurry was poured into the measuring cylinder and left for $2 \mathrm{~h}$. After that time, the volume of liquid separated from the slurry was measured and the free water was calculated.

\subsubsection{Non-Destructive Compressive Strength Test}

Ultrasonic Cement Analyser (UCA) with a SGSM device was used to perform continuous, non-destructive compressive strength tests as a function of the time of cement slurries and stones in HPHT simulated wellbore conditions. The addition of a SGSM device enabled measurements of slurry gelation and determining the so-called TT transition time.

\subsubsection{Destructive Compressive Strength Test}

Specimens for compressive strength testing using the destructive method were prepared using specially made moulds $(2 \mathrm{~cm} \times 2 \mathrm{~cm} \times 10 \mathrm{~cm}$ beams $)$ and stored in water baths at appropriate temperature. After $2,7,14$, and 28 days, the compression strength was measured with a universal testing machine.

\subsubsection{Pore Size Distribution and Porosity}

Pore distribution in the slurry was measured using the AutoPore IV Model 9500 mercury porosimeter. Glass penetrometers with specimens that are filled with mercury during the test were placed in the device ports. Before testing, the specimens were thoroughly dried in a drying oven (drying time $24 \mathrm{~h}$, temperature $105^{\circ} \mathrm{C}$ ).

Table 3 presents the testing apparatus used to perform laboratory examinations.

Table 3. Research apparatus used during laboratory tests.

\begin{tabular}{cc}
\hline Test Type & Name and Model of Apparatus \\
\hline Density of cement slurry & Baroid Ofite scale \\
Water settling (free water) & Calibrated measurement cylinder \\
Rheological parameters & Model 900 Ofite viscometer \\
Thickening time of cement slurry & Model 130 HPHT Ofite consistometer \\
Slurry Filtration & Model 40 Ofite Stirred Fluid Loss Tester \\
Early strength of cement stone (using a & Model 120-51 Ofite Ultrasound Cement Analyser (UCA) \\
non-destructive method) & Chandler Model 4207 strength machine \\
Strength of cement stone & AutoPore IV Model 9500 mercury porosimeter \\
Porosity of cement stone &
\end{tabular}




\section{Results and Discussion}

\subsection{Tests of Slurries and Cement Stones Containing an Addition of $n-\mathrm{SiO}_{2}$}

The tests of slurries containing $\mathrm{n}-\mathrm{SiO}_{2}$ were performed for conditions prevalent at depths of approximately 1000-2500 metres (dynamic temperatures at the order of $40-60^{\circ} \mathrm{C}$ ). Preliminary tests involved proper selection of the water-cement ratio $(\mathrm{w} / \mathrm{c})$ and the amount of added nanocomponents. As a result of a number of tests, it was concluded that the most preferable results are produced after using a water-cement ratio $(\mathrm{w} / \mathrm{c})$ of 0.48 with an $\mathrm{n}-\mathrm{SiO}_{2}$ content ranging between $0.5 \%$ and $1 \%$ in relation to the mass of dry cement. The use of smaller or larger amounts of $n-\mathrm{SiO}_{2}$ was the reason behind the deterioration of the technological parameters of cement slurries. Table 4 presents five compositions of slurries. They included: the base slurry labelled with the symbol I (with no addition of nanocomponents) and containing $0.5 \%$ and $1 \%$ of $n-\mathrm{SiO}_{2}$, for which the most preferable results were produced. Compositions marked with the symbols II and III were prepared for a temperature of $40{ }^{\circ} \mathrm{C}$ and a pressure of $14 \mathrm{MPa}$, and subsequent formulas marked IV and V were prepared for $60^{\circ} \mathrm{C}$ and a pressure of $21 \mathrm{MPa}$. The formulas of cement slurries were prepared based on tap water. In their composition they contained 3\% of potassium chloride and additives to slurries commonly used in drilling, such as: a liquefying additive (plasticiser), a defoamer (an agent putting out foam), an anti-filtration additive (reducing free water from the slurry), and a binding time retardant (a lignosulphonate additive responsible for regulation of the binding process). In order to achieve a proper thickening and binding time, $0.05 \%$ of the binding time retardant was used in a temperature of $40{ }^{\circ} \mathrm{C}$, with $0.15 \%$ of this agent used in a temperature of $60^{\circ} \mathrm{C}$. The slurries were prepared based on class $\mathrm{G}$ drilling cement. The produced test results for slurries under the conditions of HPHT are presented in Table 5 . The densities of the tested formulas were $1870 \mathrm{~kg} / \mathrm{m}^{3}$, with zero water settling (free water did not occur). The adjustment of the thickening times of slurries proceeded so as to enable safe pumping of slurry into the annular space of the borehole (these times ranged between approximately 3 and approximately $5 \mathrm{~h}$ ).

Table 4. Compositions of tested cement slurries with an addition of $\mathrm{n}-\mathrm{SiO}_{2}$.

\begin{tabular}{|c|c|c|c|c|c|}
\hline Slurry symbol/Components in [\%] Bwoc* & Slurry I & Slurry II & Slurry III & Slurry IV & Slurry V \\
\hline Tap water & 48 & 48 & 48 & 48 & 48 \\
\hline Nanosilica n-SiO ${ }_{2}$ & - & 0.5 & 1 & 0.5 & 1.0 \\
\hline $\mathrm{KCl}^{* *}$ & 3.0 & 3.0 & 3.0 & 3.0 & 3.0 \\
\hline Defoamer (putting out foam) & 0.5 & 0.5 & 0.5 & 0.3 & 0.3 \\
\hline Liquefying additive (plasticiser) & 0.3 & 0.3 & 0.3 & 0.2 & 0.2 \\
\hline Anti-filtration additive (limiting free water) & 0.2 & 0.2 & 0.2 & 0.3 & 0.3 \\
\hline Setting time retardant (lignosulphonate) & 0.05 & 0.05 & 0.05 & 0.15 & 0.15 \\
\hline Class $\mathrm{G}$ drilling cement & 100 & 100 & 100 & 100 & 100 \\
\hline
\end{tabular}

$\left(^{*}\right)$ bwoc: i.e., in relation to dry cement mass, $\left(^{* *}\right) \mathrm{KCl}$ was added in relation to the mass of batched water (bwow).

\subsubsection{Compressive Strength}

Tests for formulas were also performed using an ultrasound cement analyser (UCA). As a result of the examinations, it can be noticed that the tested formulas reach an early compressive strength of $3.5 \mathrm{MPa}$ after a time of approximately 8 to $14 \mathrm{~h}$. An early compressive strength value of $3.5 \mathrm{MPa}$ reached by set cement slurry allows the performance of further operations in the borehole. After $48 \mathrm{~h}$, the values of compressive strength reach approximately $25-27 \mathrm{MPa}$ for samples with an addition of $0.5 \% \mathrm{n}-\mathrm{SiO}_{2}$ and approximately $29-31 \mathrm{MPa}$ for samples with $1 \% \mathrm{n}-\mathrm{SiO}_{2}$. After 28 days of hydration, compressive strength was tested after preparing and setting cement stone cubes. For samples containing $0.5 \%$ $\mathrm{n}-\mathrm{SiO}_{2}$, the compressive strength amounted to approximately $35 \mathrm{MPa}$. On the other hand, the strength of samples containing $1 \% \mathrm{n}-\mathrm{SiO}_{2}$ was approximately $38 \mathrm{MPa}$. Dębińska [18] said that with the increase in the amount of nanosilica, the compressive strength increased. The highest results were obtained for concentrations at the level of $1.5 \%$. The addition $n-\mathrm{SiO}_{2}$ in amount of $0.1 \%$ caused an increase in compressive strength by $60 \%$ [16]. 
Table 5. Parameters of slurries and cement stones with an addition of $\mathrm{n}-\mathrm{SiO}_{2}$ tested under HPHT conditions.

\begin{tabular}{|c|c|c|c|c|c|}
\hline $\begin{array}{l}\text { Slurry Symbol, Temperature and } \\
\text { Pressure/Assayed Parameter }\end{array}$ & Slurry I & $\begin{array}{c}\text { Slurry II } \\
\left(40^{\circ} \mathrm{C} / 14 \mathrm{MPa}\right)\end{array}$ & $\begin{array}{c}\text { Slurry III } \\
\left(40^{\circ} \mathrm{C} / 14 \mathrm{MPa}\right)\end{array}$ & $\begin{array}{l}\text { Slurry IV } \\
\left(60^{\circ} \mathrm{C} / 21 \mathrm{MPa}\right)\end{array}$ & $\begin{array}{c}\text { Slurry V } \\
\left(60^{\circ} \mathrm{C} / 21 \mathrm{MPa}\right)\end{array}$ \\
\hline Density of cement slurry $\left[\mathrm{kg} / \mathrm{m}^{3}\right]$ & 1870 & 1870 & 1870 & 1870 & 1870 \\
\hline $\begin{array}{l}\text { Water settling from slurry (free water) measured at } \\
\text { an angle of } 90^{\circ}[\%]\end{array}$ & 0.8 & 0.0 & 0.0 & 0.0 & 0.0 \\
\hline Plastic viscosity of slurry $\left[\mathrm{Pa}^{*} \mathrm{~s}\right]$ & 0.1008 & 0.1043 & 0.1058 & 0.1329 & 0.1468 \\
\hline Yield point of slurry [Pa] & 3.4 & 3.8 & 4.1 & 5.6 & 6.2 \\
\hline $\begin{array}{l}\text { Time needed for the slurry to reach a consistency of } \\
30 \mathrm{Bc} \text { under HPHT conditions [hours-minutes] }\end{array}$ & $3 \mathrm{~h} 50 \mathrm{~min}$. & $3 \mathrm{~h} 46 \mathrm{~min}$. & 2 h 59 min. & $3 \mathrm{~h} 22 \mathrm{~min}$. & $2 \mathrm{~h} 39 \mathrm{~min}$. \\
\hline $\begin{array}{l}\text { Time needed for the slurry to reach a consistency of } \\
100 \text { Bc under HPHT conditions [hours-minutes] }\end{array}$ & $5 \mathrm{~h} 58 \mathrm{~min}$. & $5 \mathrm{~h} 07 \mathrm{~min}$. & $4 \mathrm{~h} 10 \mathrm{~min}$. & $3 \mathrm{~h} 47 \mathrm{~min}$. & $3 \mathrm{~h} 04 \mathrm{~min}$. \\
\hline $\begin{array}{c}\text { Time until achieving early compressive strength } \\
\text { amounting to } 3.5 \text { [MPa] }\end{array}$ & $16 \mathrm{~h}$ & $10 \mathrm{~h}$ & $13 \mathrm{~h}$ & $14 \mathrm{~h}$ & $8 \mathrm{~h}$ \\
\hline Filtration, $\left(\mathrm{cm}^{3}\right)$ After $30 \mathrm{~min}$ of Measurement & 244 & 190 & 182 & 164 & 156 \\
\hline $\begin{array}{l}\text { Compressive strength of cement stone after } 48 \mathrm{~h} \text { of } \\
\text { hydration (UCA apparatus measurement) [MPa] }\end{array}$ & 26.1 & 27.4 & 31.2 & 25.3 & 28.9 \\
\hline $\begin{array}{l}\text { Compressive strength of cement stone after } 28 \text { days } \\
\text { of hydration [MPa] }\end{array}$ & 31.2 & 34.4 & 37.1 & 36.4 & 38.7 \\
\hline $\begin{array}{l}\text { The share of pores with diameters above } 10,000 \mathrm{~nm} \\
\text { in the whole cement stone matrix [\%] }\end{array}$ & 5.5 & 2.7 & 2.0 & 1.4 & 2.8 \\
\hline $\begin{array}{l}\text { The share of pores with diameters of } 100-10,000 \mathrm{~nm} \\
\text { in the whole cement stone matrix }[\%]\end{array}$ & 6.1 & 0.7 & 1.4 & 0.3 & 2.1 \\
\hline $\begin{array}{c}\text { The share of pores with diameters below } 100 \mathrm{~nm} \text { in } \\
\text { the whole cement stone matrix [\%] }\end{array}$ & 88.4 & 96.6 & 96.6 & 98.3 & 95.1 \\
\hline
\end{tabular}

\subsubsection{Porosity and Pore Size Distribution}

One should also point out the highly advantageous parameters of microstructure generated from cement slurries containing nanocomponents. The share of pores with diameters above 10,000 $\mathrm{nm}$ in the whole cement stone matrix was as low as approximately $2 \%$, while the share of pores with diameters below $100 \mathrm{~nm}$ was as high as approximately $95-98 \%$. This fact proves that cement matrix thickened by $\mathrm{n}-\mathrm{SiO}_{2}$ is exceptionally tight. Dębińska [16] and Rzepka and Kędzierski [43] reported that obtained set cement slurries had low porosity and their pore distribution were characterized by a small number of pores with diameters greater than $100 \mathrm{~nm}$, in the range $1.3-2.5 \%$, which prove their compact structure. It is difficult to directly compare parameters produced for slurries described above to parameters of conventional slurries, mainly because the introduction of an addition of nanoparticles entails a change in the composition of the formula (including a change in the water-cement ratio, the amount of the liquefying agent and the anti-filtering agent). Conventional formulas generally have significantly higher water settling compared to slurries with n-SiO ${ }_{2}$. Similarly to Dębińska [16], it was found that nanosilica reduces the thickening time of slurry with its addition, compared to the conventional cement slurry. Additionally, cement stone generated from conventional slurries has a noticeably lower strength, and its structure is considerably less compact than in slurries containing nanocomponents.

\subsubsection{Microstructure}

The exceptionally uniform microstructure of samples with n- $\mathrm{SiO}_{2}$ can be confirmed by photographs of set slurry samples taken using scanning microscopy. Figure $4 \mathrm{a}, \mathrm{b}$ (magnification $1000 \times$ ) present the average microstructure of conventional slurry, i.e., with no addition of nanocomponents. On these photographs there are visible pores of quite large sizes, which after merging can form channels in the cement mantle and cause possible flow of gas in the annular space of the borehole. Due to the introduction of $1 \%$ of nanosilica $\left(\mathrm{n}-\mathrm{SiO}_{2}\right)$ into the sample, the structure of set slurry is considerably thickened (Figure $5 a, b)$. It can be clearly observed that cement matrix modified with $n-\mathrm{SiO}_{2}$ is much more compact compared to a matrix created by conventional slurry (the areas of macropores are not visible in Figure 5a,b). Biricik show that the scanning microscopy (SEM) images after 7 days of curing show condensed packing of cement hydration products. The SEM study of the microstructures between the cement mortar mixed with the nano-particles and the plain cement mortar showed 
that the nano-SiO 2 filled up the pores and reduced $\mathrm{CaOH}_{2} \mathrm{compound}$ among the hydrates [7]. Rzepka i Kędzierski [43] reported that the extremely compact microstructure of the samples with nano- $\mathrm{SiO}_{2}$ is confirmed by scanning electron microscope images of cement samples. They show a compact cement matrix with very low permeability. Moreover, set slurry modified by n-SiO 2 exhibits very high tightness and low porosity.

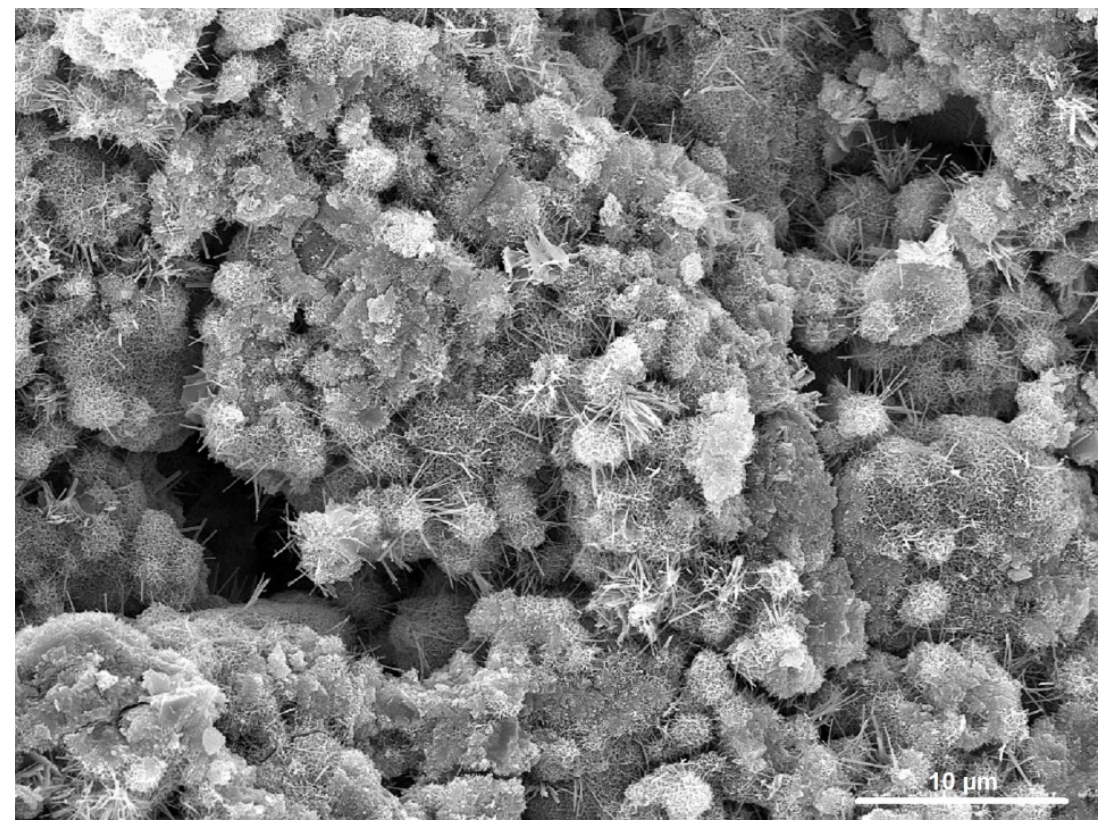

(a)

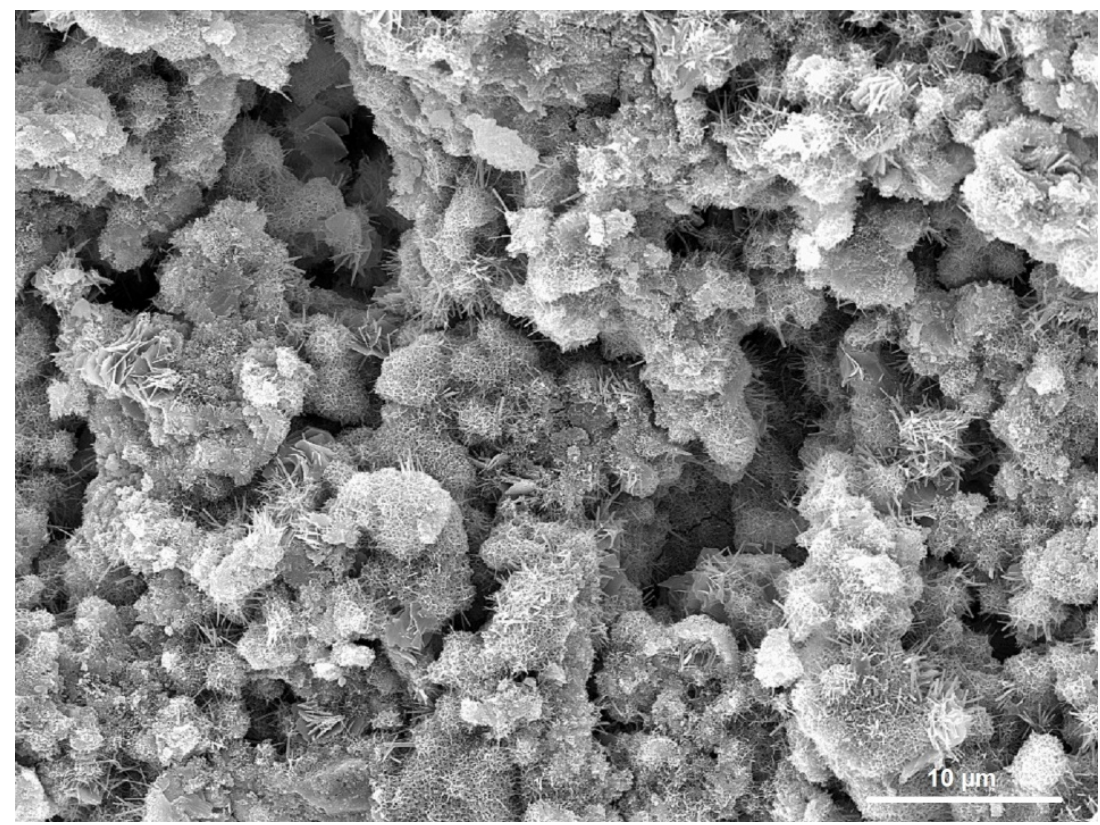

(b)

Figure 4. (a). Sample microstructure of "conventional" cement slurry (with no addition of n $-\mathrm{SiO}_{2}$ ). Magnification 1000×. (b). Sample microstructure of "conventional" cement slurry (with no addition of $\mathrm{n}-\mathrm{SiO}_{2}$ ). Magnification $1000 \times$. 


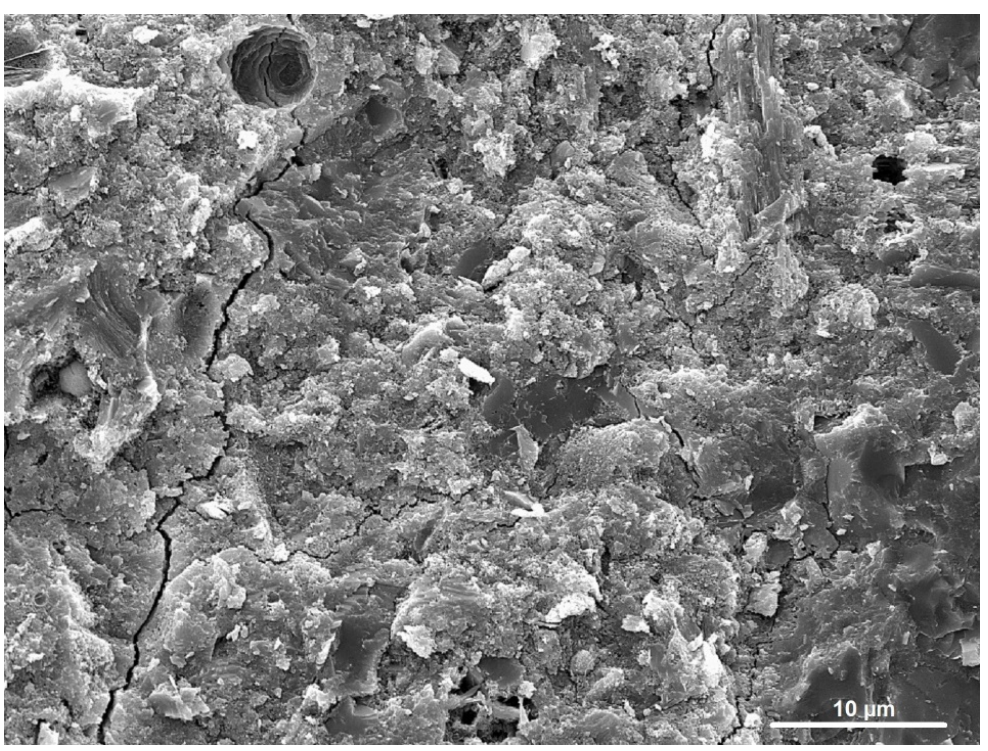

(a)

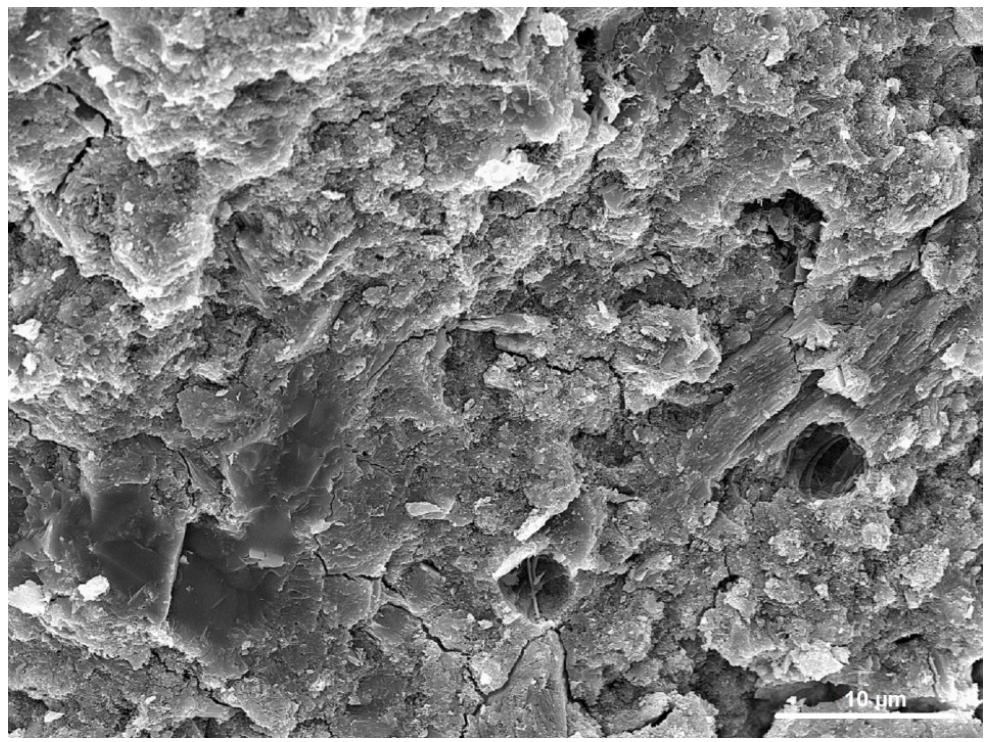

(b)

Figure 5. (a). Sample microstructure of cement slurry containing $1 \% \mathrm{n}-\mathrm{SiO}_{2}$. Magnification $1000 \times$. (b). Sample microstructure of cement slurry containing $1 \% \mathrm{n}-\mathrm{SiO}_{2}$. Magnification $1000 \times$.

\subsection{Tests of Slurries and Cement Stones Containing an Addition of $n-\mathrm{Al}_{2} \mathrm{O}_{3}$}

The performed tests of slurries with an addition of $n-\mathrm{Al}_{2} \mathrm{O}_{3}$ focused on formulas which could be useful when sealing boreholes at depths of 2000-2500 metres (having chosen a dynamic temperature of $60{ }^{\circ} \mathrm{C}$ at the bottom of the well). The preliminary tests of slurries with nanosized alumina were aimed at proper selection of the water-cement ratio $(\mathrm{w} / \mathrm{c})$ and the amount of nanoparticles in batched water. After the performance of trial analyses, it was concluded that the most advantageous results are produced using coefficients of 0.44 (for slurries based on class $G$ drilling cement).

The compositions of cement slurries for which the tests were performed are presented in Table 6 . The tests involved four cement slurries. They included: the base slurry labelled with the symbol VI (with no addition of nanocomponents), as well as slurries containing $1 \%, 3 \%$, and $5 \%$ of $n-\mathrm{Al}_{2} \mathrm{O}_{3}$ (marked with the symbols VII, VIII, and IX, respectively). All of the tested slurries (similar to compositions with $\mathrm{n}-\mathrm{SiO}_{2}$ ) contained a defoamer, a liquefying additive, and an additive extending the time of thickening and setting. Class $\mathrm{G}$ drilling cement also constituted a binding cement. 
Table 6. Compositions of tested cement slurries with an addition of $n-\mathrm{Al}_{2} \mathrm{O}_{3}$.

\begin{tabular}{ccccc}
\hline Slurry Symbol/Components in [\%] Bwoc * & Slurry VI & Slurry VII & Slurry VIII & Slurry IX \\
\hline Tap water, w/c & 0.44 & 0.44 & 0.44 & 0.44 \\
Nanosized alumina n- $\mathrm{Al}_{2} \mathrm{O}_{3}$ & - & 1 & 3 & 5 \\
$\mathrm{KCl}^{* *}$ & 3.0 & 3.0 & 3.0 & 3.0 \\
Defoamer (putting out foam) & 0.5 & 0.5 & 0.5 & 0.5 \\
Liquefying additive (plasticiser) & 0.1 & 0.1 & 0.1 & 0.1 \\
Setting time retardant (lignosulphonate) & 0.3 & 0.3 & 0.3 & 0.3 \\
Drilling cement G & 100 & 100 & 100 & 100 \\
\hline
\end{tabular}

$\left({ }^{*}\right)$ bwoc: i.e., in relation to dry cement mass, $\left({ }^{* *}\right) \mathrm{KCl}$ was added in relation to the mass of batched water (bwow).

\subsubsection{The Measurements of Liquid Cement Slurries}

Table 7 presents the produced test results. The base slurry marked with the symbol VI had a density of $1900 \mathrm{~kg} / \mathrm{m}^{3}$. A slight increase in the density of slurries was observed along with an increase in the concentration of nanosized alumina. Hadi et al. [26] stated that the effect of nanosized alumina on density is very small. Slurry VIII with $3 \%$ of $n-\mathrm{Al}_{2} \mathrm{O}_{3}$ had a density of $1910 \mathrm{~kg} / \mathrm{m}^{3}$, while slurry IX with $5 \%$ of $n-\mathrm{Al}_{2} \mathrm{O}_{3}$ had $1920 \mathrm{~kg} / \mathrm{m}^{3}$. The water settling of the base slurry was $0.3 \%$. After the addition of $\mathrm{n}-\mathrm{Al}_{2} \mathrm{O}_{3}$, the water settling of slurries amounted to zero. An addition of $\mathrm{n}-\mathrm{Al}_{2} \mathrm{O}_{3}$ into oil well cement gives better results by reducing free water of slurry [26]. An increase in plastic viscosity and yield point was observed following an increase in the amount of $n-\mathrm{Al}_{2} \mathrm{O}_{3}$ in slurries. For example, slurry marked with the symbol VI with no addition of nanosized alumina had a viscosity of $87 \mathrm{mPa} \cdot \mathrm{s}$ and a the yield point of $3.4 \mathrm{~Pa}$, while after the addition of $3 \%$ of $n-\mathrm{Al}_{2} \mathrm{O}_{3}$ to the slurry marked with the symbol VIII, viscosity increased up to $151.5 \mathrm{mPa} \cdot \mathrm{s}$ and yield point up to $5.5 \mathrm{~Pa}$. According to Hadi [26] an increase concentration in $\mathrm{n}-\mathrm{Al}_{2} \mathrm{O}_{3}$ resulted in higher plastic viscosity, yield point and gel strength for oil well cement. Under the conditions of HPHT $\left(60^{\circ} \mathrm{C}, 25 \mathrm{MPa}\right)$, the thickening times were also tested, i.e., the times needed for the slurries to reach consistencies of $30 \mathrm{Bc}$ and $100 \mathrm{Bc}$. Shortening of the thickening times along with an increase in the concentration of $n-\mathrm{Al}_{2} \mathrm{O}_{3}$ was observed during the tests. Cement slurry marked with the symbol VIII, containing $3 \%$ of $n-\mathrm{Al}_{2} \mathrm{O}_{3}$, was characterised by optimal parameters in terms of thickening time, for which a consistency of $30 \mathrm{Bc}$ was reached after $2 \mathrm{~h}$ $58 \mathrm{~min}$, with $100 \mathrm{Bc}$ after $4 \mathrm{~h} 3 \mathrm{~min}$. Determination of the parameters of cement stones was commenced upon completion of the measurements of liquid cement slurries.

\subsubsection{Compressive Strength}

Sample results of tests involving the increase in early strength produced from an ultrasound cement analyser (UCA) for slurry marked with the symbol VIII containing $3 \%$ of $n-\mathrm{Al}_{2} \mathrm{O}_{3}$ are presented in Figure 6. From the UCA test, it is visible that already after $12 \mathrm{~h}$ the strength of cement stone was approximately $21 \mathrm{MPa}$, and after $24 \mathrm{~h}$ it was approximately $25 \mathrm{MPa}$. At a later time during the test, there was a further increase in compressive strength up to a value of approximately $31 \mathrm{MPa}$ after $48 \mathrm{~h}$. Patil and Deshpande [1] reports that the addition of nano-alumina resulted in achieving early compressive strength even at low temperatures. Li et al. [8] show that the compressive strength of composites increased by $30 \%$ at 7 days. The cement stones prepared from cement slurries with nanoparticles were characterized by high values of compressive strength, which was caused by packing of the small size nanoparticles in the pore spaces [15]. The results of early strength tests for all samples examined in a temperature of $60^{\circ} \mathrm{C}$ are listed in Table 5 in the final row. All of the tested slurries were also set in an autoclave (in a temperature of $60^{\circ} \mathrm{C}$ and a pressure of $25 \mathrm{MPa}$ ), followed by the measurements of compressive strength performed for them after 2, 7, 14, and 28 days of deposition. The results are presented graphically in Figure 7. Slurry VIII containing 3\% of $n-\mathrm{Al}_{2} \mathrm{O}_{3}$ had the highest strength parameters. Its compressive strength after 28 days reached $40 \mathrm{MPa}$. Additionally, it should be pointed out that slurry IX with a higher (5\%) concentration of nanosized alumina had the lowest compressive strength among the tested samples. This fact can be explained by difficulties in the uniform distribution of large amounts of nanoparticles in the slurry and the possible generation of 
large agglomerates. Therefore, the so-called "nanoscale effect" can be no longer active once the solution has exceeded a certain concentration of nanoparticles.

\subsubsection{Microstructure}

Attention should also be paid to the highly advantageous parameters of microstructure generated from cement slurries containing nanosized alumina. This is clearly visible in photographs of set slurry samples taken by means of scanning microscopy (SEM). Figure $8 \mathrm{a}, \mathrm{b}$ (with the respective magnifications of $500 \times$ and $1300 \times$ ) present a typical image of base slurry microstructure not containing an addition of nanosized alumina. In there, pores with quite large dimensions can be observed, which when merged with each other can generate channels in the set cement stone, due to which possible flow of gas in the annular space of the borehole can take place upon the completion of the cementing process. After applying a modification which used $3 \%$ of nanosized alumina $\left(n-\mathrm{Al}_{2} \mathrm{O}_{3}\right)$, the structure of the cement stone was thickened considerably. The pores were also filled with nanoparticles (Figure 9a,b: $9 a-$ magnification $500 \times$ and $9 \mathrm{~b}$-magnification 1300×). Therefore, it can be seen that cement matrix modified with nanocomponents is exceptionally compact and no macropore areas are observed in it. Therefore, cement stone modified by an addition of $\mathrm{n}-\mathrm{Al}_{2} \mathrm{O}_{3}$ exhibits very high tightness. Porosity of cement decreased by incorporating nano-alumina into mortars [8].

\subsection{Tests of Slurries and Cement Stones Containing an Addition of Multi-Walled Carbon Nanotubes (MWCNTs)}

The tests of cement slurries containing multi-walled carbon nanotubes were performed in temperatures of $25-30{ }^{\circ} \mathrm{C}$. Preliminary tests involved determination of the compositions of base slurries, the proper water-cement ratio $(\mathrm{w} / \mathrm{c})$ and the number of used carbon nanotubes. Upon performing a number of tests, it was concluded that the most preferable results are produced with a water-cement ratio of $0.45-0.49$ and with MWCNT contents amounting to $0.1 \%$ and $0.2 \%$ in relation to dry cement mass. The use of a larger number of carbon nanotubes was the cause of lower values of compressive strength reached by cement stone. Table 8 presents four compositions of cement slurries marked with the symbols: X, XI, XII, XIII. The base slurry was marked with the symbol X (no addition of carbon nanotubes). Formulas labelled XI and XII contained $0.1 \%$ of MWCNTs, while slurry XIII contained an addition of multi-walled carbon nanotubes amounting to $0.2 \%$. All prepared slurries were based on tap water. In their composition they contained $3 \% \mathrm{KCl}$ and a liquefying additive, a defoamer, an anti-filtering additive, an additive accelerating the $\mathrm{CaCl}_{2}$ binding time, and a swelling additive. The prepared slurries were based on Portland cement CEM I 42.5R.

Table 7. The parameters of cement slurries and cement stones with an addition of $\mathrm{n}-\mathrm{Al}_{2} \mathrm{O}_{3}$ tested under HPHT conditions.

\begin{tabular}{|c|c|c|c|c|}
\hline $\begin{array}{l}\text { Slurry Symbol, Temperature and } \\
\text { Pressure/Assayed Parameter }\end{array}$ & $\begin{array}{c}\text { Slurry VI } \\
\left(60^{\circ} \mathrm{C} / 25 \mathrm{MPa}\right)\end{array}$ & $\begin{array}{c}\text { Slurry VII } \\
\left(60^{\circ} \mathrm{C} / 25 \mathrm{MPa}\right)\end{array}$ & $\begin{array}{c}\text { Slurry VIII } \\
\left(60^{\circ} \mathrm{C} / 25 \mathrm{MPa}\right)\end{array}$ & $\begin{array}{c}\text { Slurry IX } \\
\left(60^{\circ} \mathrm{C} / 25 \mathrm{MPa}\right)\end{array}$ \\
\hline Slurry density $\left[\mathrm{kg} / \mathrm{m}^{3}\right]$ & 1900 & 1905 & 1910 & 1920 \\
\hline $\begin{array}{l}\text { Water settling from slurry measured at an } \\
\text { angle of } 90^{\circ}[\%]\end{array}$ & 0.3 & 0.0 & 0.0 & 0.0 \\
\hline Plastic viscosity of slurry $\left[\mathrm{mPa}^{*} \mathrm{~s}\right]$ & 87.0 & 117.0 & 151.5 & 172.5 \\
\hline Yield point of slurry [Pa] & 3.4 & 4.3 & 5.5 & 6.0 \\
\hline $\begin{array}{c}\text { Time needed for the slurry to reach a } \\
\text { consistency of } 30 \mathrm{Bc} \text { under HPHT conditions } \\
\text { [hours: minutes] }\end{array}$ & $3 \mathrm{~h} 51 \mathrm{~min}$. & $3 \mathrm{~h} 32 \mathrm{~min}$. & $2 \mathrm{~h} 58 \mathrm{~min}$. & $2 \mathrm{~h} 35 \mathrm{~min}$. \\
\hline $\begin{array}{l}\text { Time needed for the slurry to reach a } \\
\text { consistency of } 100 \text { Bc under HPHT conditions } \\
\text { [hours: minutes] }\end{array}$ & $5 \mathrm{~h} 02 \mathrm{~min}$. & $4 \mathrm{~h} 46 \mathrm{~min}$. & 4 h 03 min. & $3 \mathrm{~h} 48 \mathrm{~min}$. \\
\hline Filtration, $\left(\mathrm{cm}^{3}\right)$ After $30 \mathrm{~min}$ of Measurement & 296 & 212 & 208 & 290 \\
\hline $\begin{array}{l}\text { Early compressive strength of cement stone } \\
\text { after } 48 \mathrm{~h} \text { of hydration-UCA test [MPa] }\end{array}$ & 25.9 & 28.2 & 31.0 & 24.4 \\
\hline
\end{tabular}




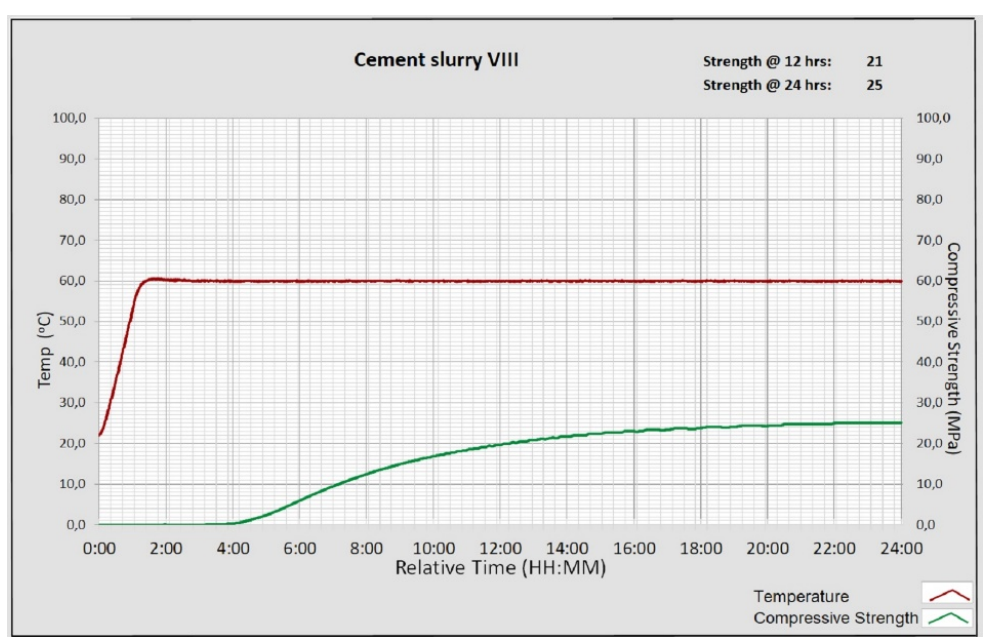

Figure 6. An increase in the early mechanical strength of sample VIII.

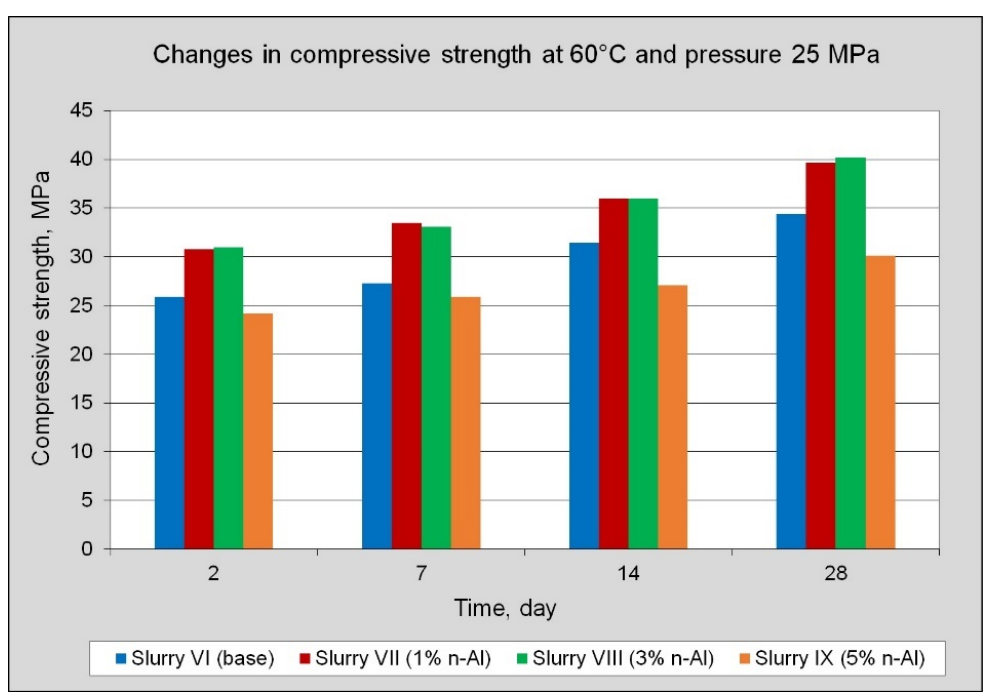

Figure 7. Changes in the compressive strength of samples VI, VII, VIII, IX after 2, 7, 14, and 28 days of hydration.

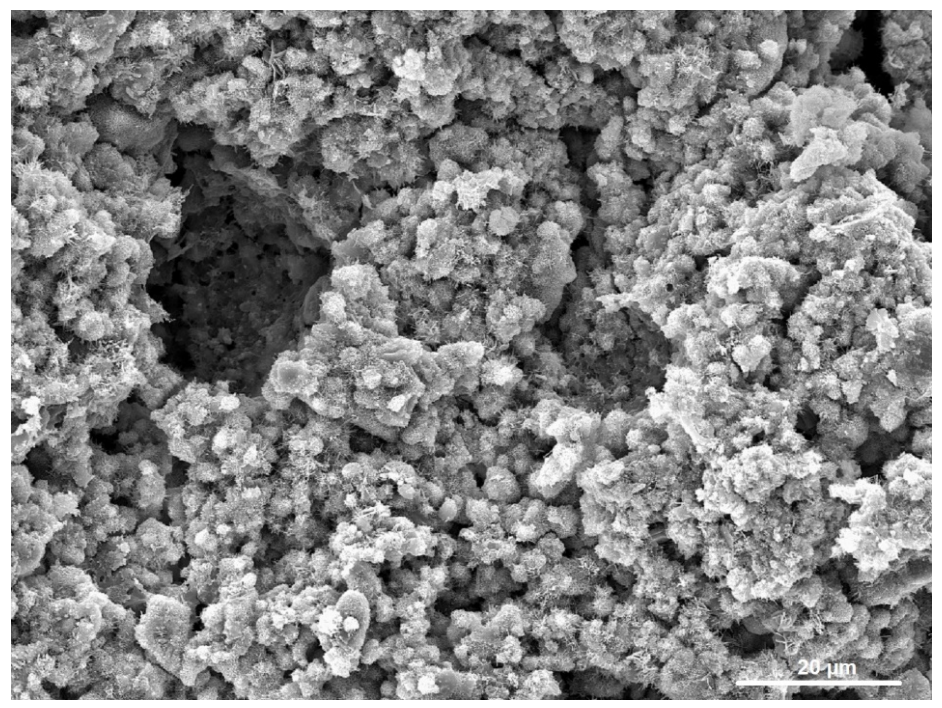

(a)

Figure 8. Cont. 


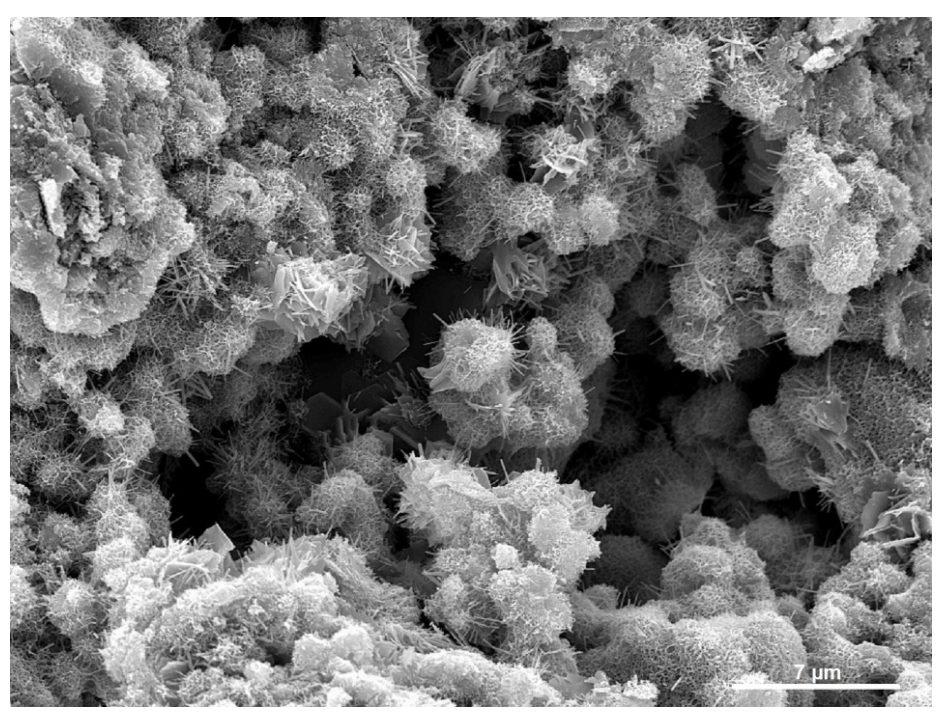

(b)

Figure 8. (a). Sample microstructure of "conventional" cement slurry (with no addition of n- $\mathrm{Al}_{2} \mathrm{O}_{3}$ ). Magnification 500×. (b). Sample microstructure of "conventional" cement slurry (with no addition of $\mathrm{n}-\mathrm{Al}_{2} \mathrm{O}_{3}$ ). Magnification $1300 \times$.

Table 8. Compositions of tested cement slurries with an addition of MWCNTs.

\begin{tabular}{ccccc}
\hline Slurry Symbol/Components in [\%] Bwoc * & Slurry X & Slurry XI & Slurry XII & Slurry XIII \\
\hline Tap water, w/c & 0.47 & 0.47 & 0.45 & 0.49 \\
Multi-walled carbon nanotubes (MWCNTs) & - & 0.1 & 0.1 & 0.2 \\
KCl ${ }^{* *}$ & 3.0 & 3.0 & 3.0 & 3.0 \\
Defoamer (putting out foam) & 0.2 & 0.2 & 0.2 & 0.2 \\
Liquefying additive (plasticiser) & 0.05 & 0.05 & 0.05 & 0.1 \\
Anti-filtration additive (limiting free water) & 0.3 & 0.3 & 0.3 & 0.3 \\
Setting stimulant (CaCl $_{\text {) }}$ & 1.0 & 1.0 & 1.5 & 1.0 \\
Portland cement CEM I 42,5R & 100 & 100 & 100 & 100 \\
Swelling additive & 0.3 & 0.3 & - & 0.3 \\
\hline
\end{tabular}

$\left({ }^{*}\right)$ bwoc: i.e., in relation to dry cement mass, $\left.{ }^{* *}\right) \mathrm{KCl}$ was added in relation to the mass of batched water (bwow).

\subsubsection{The Measurements of Liquid Cement Slurries}

Table 9 presents the results of laboratory tests. The base slurry labelled with the symbol X was characterised by a density of $1860 \mathrm{~kg} / \mathrm{m}^{3}$. Slurries XI and XII with an addition of $0.1 \%$ of MWCNTs had a density of $1870 \mathrm{~kg} / \mathrm{m}^{3}$, while slurry XIII with $0.2 \%$ of MWCNTs had a density of $1830 \mathrm{~kg} / \mathrm{m}^{3}$. All slurries were characterised by zero water settling. The addition of multi-walled carbon nanotubes caused an increase in plastic viscosity and a drop in the flowability of cement slurries. De Paula et al. [36] show that the addition of CNTs does not alter the rheological behaviour and stability of the cement slurries considering the dispersant and concentrations employed. The thickening times of slurries were tested under simulated well conditions $\left(30^{\circ} \mathrm{C}, 10 \mathrm{MPa}\right)$. Slurry marked with the symbol XI containing $0.1 \%$ of MWCNTs was characterised by the most advantageous parameters in terms of thickening time, for which a consistency of $30 \mathrm{Bc}$ was reached after $2 \mathrm{~h}$ and $44 \mathrm{~min}$, with $100 \mathrm{Bc}$ reached after $4 \mathrm{~h}$ and $9 \mathrm{~min}$. 


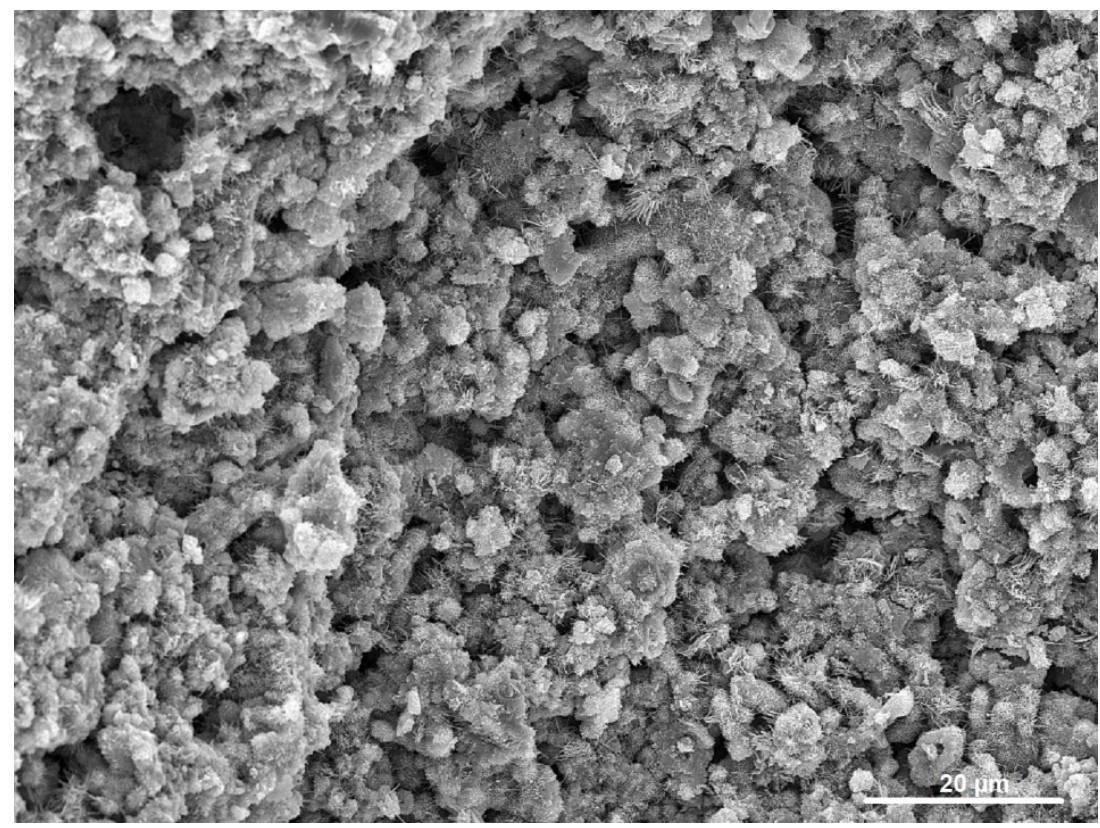

(a)

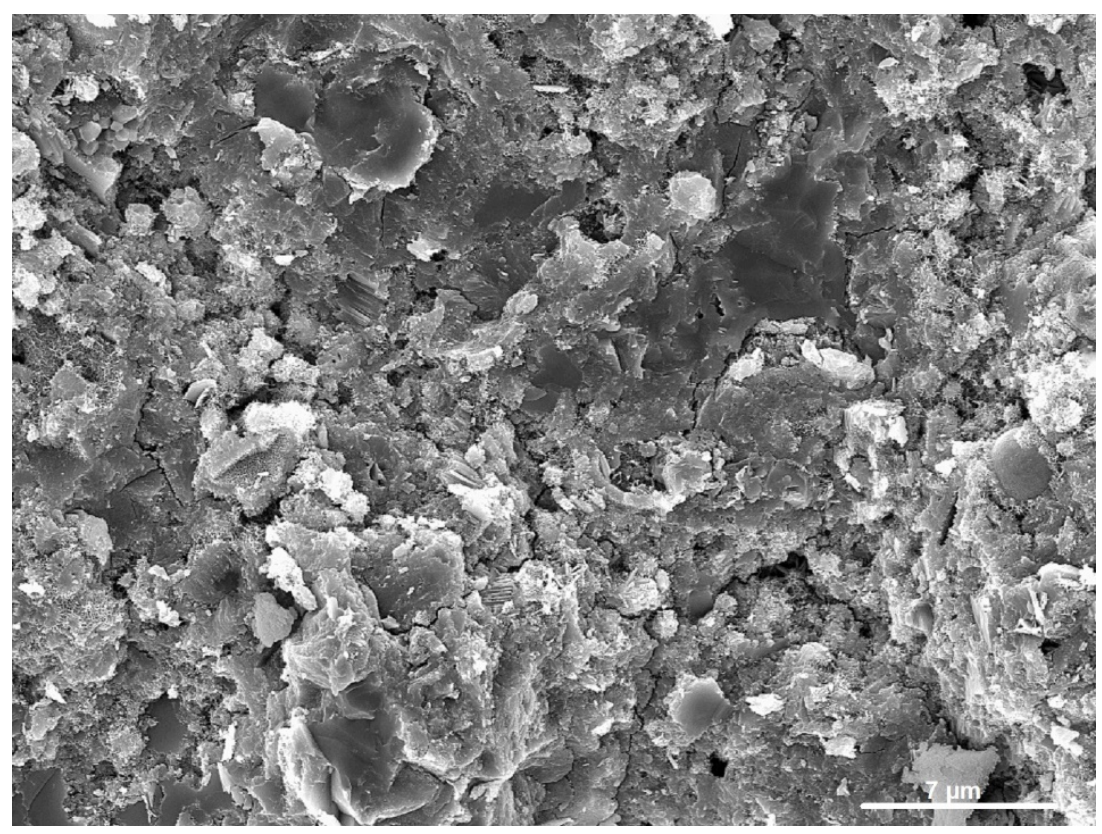

(b)

Figure 9. (a). Sample microstructure of cement slurry containing $3 \% \mathrm{n}-\mathrm{Al}_{2} \mathrm{O}_{3}$. Magnification $500 \times$. (b). Sample microstructure of cement slurry containing 3\% n- $\mathrm{Al}_{2} \mathrm{O}_{3}$. Magnification $1300 \times$. 
Table 9. Parameters of slurries and cement stones with an addition of $\mathrm{n}-\mathrm{SiO}_{2}$ tested under HPHT conditions.

\begin{tabular}{|c|c|c|c|c|}
\hline $\begin{array}{l}\text { Slurry Symbol, Temperature and } \\
\text { Pressure/Assayed Parameter }\end{array}$ & $\begin{array}{c}\text { Slurry X } \\
\left(30^{\circ} \mathrm{C} / 10 \mathrm{MPa}\right)\end{array}$ & $\begin{array}{c}\text { Slurry XI } \\
\left(30^{\circ} \mathrm{C} / 10 \mathrm{MPa}\right)\end{array}$ & $\begin{array}{c}\text { Slurry XII } \\
\left(30^{\circ} \mathrm{C} / 10 \mathrm{MPa}\right)\end{array}$ & $\begin{array}{c}\text { Slurry XIII } \\
\left(30^{\circ} \mathrm{C} / 10 \mathrm{MPa}\right)\end{array}$ \\
\hline Density of cement slurry $\left[\mathrm{kg} / \mathrm{m}^{3}\right]$ & 1860 & 1860 & 1870 & 1830 \\
\hline $\begin{array}{l}\text { Water settling from slurry (free water) } \\
\text { measured at an angle of } 90^{\circ}[\%]\end{array}$ & 0.0 & 0.0 & 0.0 & 0.0 \\
\hline Plastic viscosity of slurry $\left[\mathrm{Pa}^{*} \mathrm{~s}\right]$ & 0.147 & 0.1485 & 0.1530 & 0.1701 \\
\hline Yield point of slurry [Pa] & 3.6 & 5.0 & 3.8 & 10.6 \\
\hline $\begin{array}{l}\text { Time needed for the slurry to reach a } \\
\text { consistency of } 30 \text { Bc under HPHT } \\
\text { conditions [hours-minutes] }\end{array}$ & $2 \mathrm{~h} 21 \mathrm{~min}$. & $2 \mathrm{~h} 44 \mathrm{~min}$. & $2 \mathrm{~h} 05 \mathrm{~min}$. & $1 \mathrm{~h} 35 \mathrm{~min}$. \\
\hline $\begin{array}{l}\text { Time needed for the slurry to reach a } \\
\text { consistency of } 100 \mathrm{Bc} \text { under HPHT } \\
\text { conditions [hours-minutes] }\end{array}$ & $4 \mathrm{~h} 00 \mathrm{~min}$. & $4 \mathrm{~h} 09 \mathrm{~min}$. & $3 \mathrm{~h} 50 \mathrm{~min}$. & $4 \mathrm{~h} 25 \mathrm{~min}$. \\
\hline $\begin{array}{c}\text { Filtration, }\left(\mathrm{cm}^{3}\right) \text { After } 30 \mathrm{~min} \\
\text { of Measurement }\end{array}$ & 186 & 60 & 66 & 70 \\
\hline $\begin{array}{l}\text { Compressive strength of cement stone } \\
\text { after } 28 \text { days of hydration [MPa] }\end{array}$ & 33.4 & 47.5 & 50.5 & 36.8 \\
\hline $\begin{array}{l}\text { The share of pores with diameters } \\
\text { above } 10,000 \mathrm{~nm} \text { in the whole cement } \\
\text { stone matrix [\%] }\end{array}$ & 1.4 & 1.5 & 1.3 & 1.3 \\
\hline $\begin{array}{c}\text { The share of pores with diameters of } \\
100-10,000 \mathrm{~nm} \text { in the whole cement } \\
\text { stone matrix [\%] }\end{array}$ & 34.8 & 1.3 & 0.7 & 1.6 \\
\hline $\begin{array}{c}\text { The share of pores with diameters } \\
\text { below } 100 \mathrm{~nm} \text { in the whole cement } \\
\text { stone matrix [\%] }\end{array}$ & 63.8 & 97.2 & 98.0 & 97.1 \\
\hline
\end{tabular}

\subsubsection{Compressive Strength}

Samples for compressive strength tests using a destructive method were made by means of specially prepared moulds (bars with dimensions of $2 \mathrm{~cm} \times 2 \mathrm{~cm} \times 10 \mathrm{~cm}$ ) and stored in water baths in proper temperature $\left(30^{\circ} \mathrm{C}\right)$. After $2,7,14$, and 28 days, measurements of compressive strength were performed by means of a strength machine (destructive method). The compressive strength of cement stone generated from base slurry after 28 days amounted to $33.4 \mathrm{MPa}$. Slurry XII containing $0.1 \%$ of MWCNTs had the highest strength parameters. Its compressive strength after 28 days was as high as $50 \mathrm{MPa}$. Compared to the base sample, a 50\% increase in compressive strength was obtained, similar to Cwirzen [34]. Paula et al. [37] reported that with respect to mechanical properties, no difference in compressive strength was found between paste with and without. El-Gamal [35] improved mechanical properties of cement slurries have been achieved up on addition of $0.1 \%$ CNTs. The produced results of the compressive strength of samples are presented graphically in Figure 10.

\subsubsection{Porosity and Pore Size Distribution}

Based on the performed tests, one can notice the positive impact of carbon nanotubes on the microstructure of cement stones with their addition. Cement stones have a compact microstructure with a low share of macropores and they are characterised by low porosity. The share of pores with diameters of $10,000 \mathrm{~nm}$ constituted only approximately $1.5 \%$ of the total number of pores, while the smallest pores with diameters below $100 \mathrm{~nm}$ constituted more than $95 \%$ of all pores. It has been reported in the literature that the porosity and pore size distribution results indicated that the presence of MWCNTs reduced micropore size [23]. Figure 11a-d present the distribution of pore sizes in cement stones. 


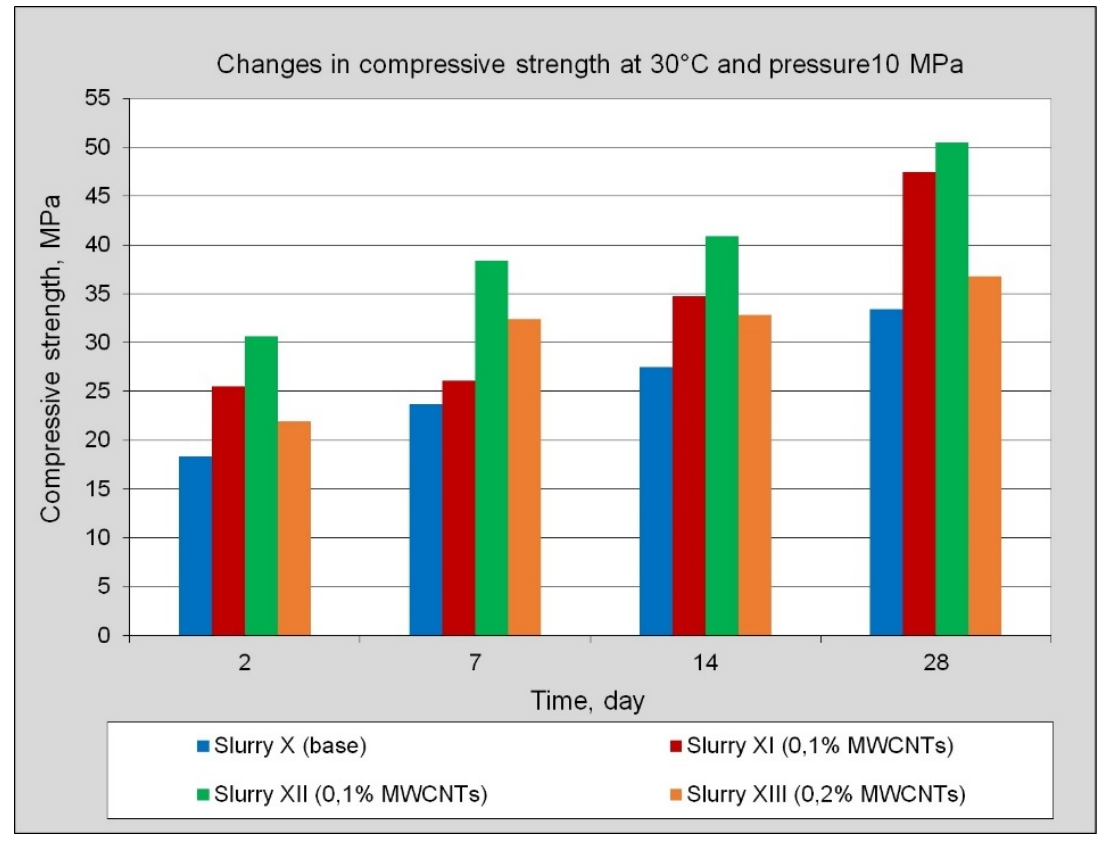

Figure 10. Changes in the compressive strength of samples X, XI, XII, XIII after 2, 7, 14, and 28 days of hydration.

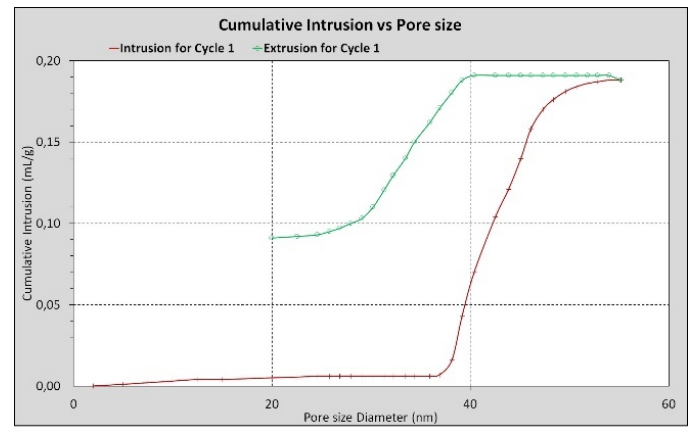

(a)

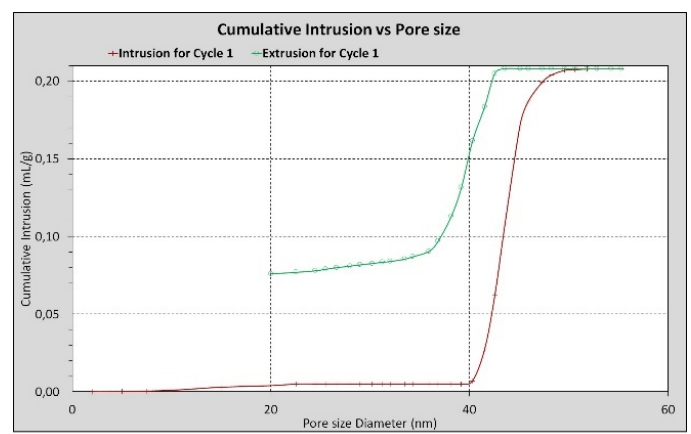

(c)

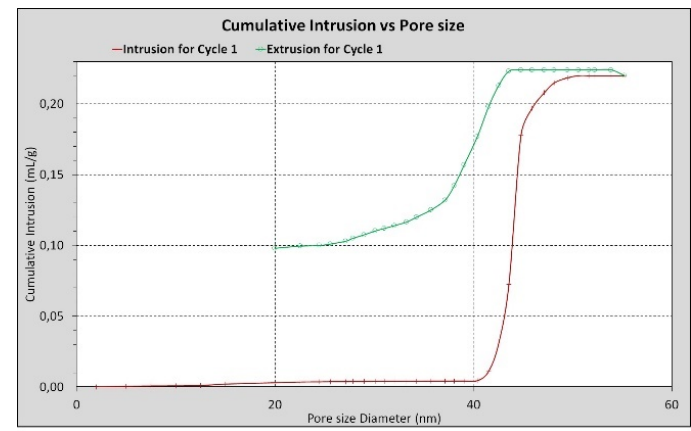

(b)

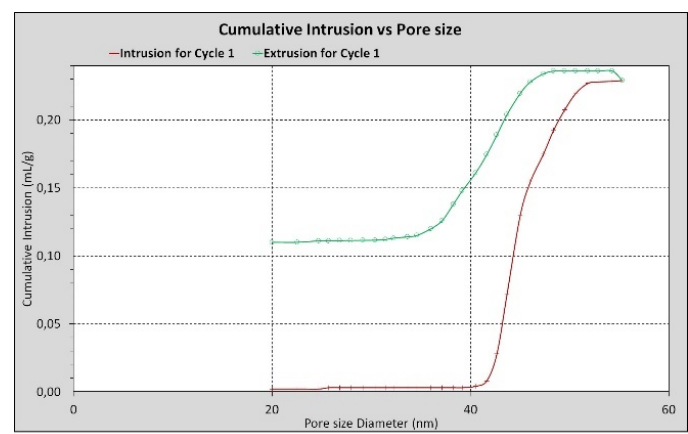

(d)

Figure 11. (a). Pore size distribution of slurry X. (b). Pore size distribution of slurry XI. (c). Pore size distribution of slurry XII. (d). Pore size distribution of slurry XIII.

\section{Conclusions}

Cement slurries with an addition of nanoparticles and carbon nanotubes presented in the paper can be a basis for the development of a wide variety of innovative formulas of slurries intended to seal boreholes with depths between several hundred and approximately two and a half thousand metres, 
in which it is required to achieve very high tightness of the cement matrix and high strength of the cement mantle.

Upon performing a series of tests, it can be concluded that these components cause an improvement in the parameters of liquid and set cement slurry. Particular attention should be paid to the fact that cement stones produced from slurries containing nanocomponents and carbon nanotubes were characterised by high values of compressive strength, which is caused by the packing of particles with very small sizes in porous spaces.

Based on the produced results it can be concluded that

- for cement slurries containing approximately $0.5-1 \% \mathrm{n}-\mathrm{SiO}_{2}$, the most preferable technological parameters were achieved with a w/c ratio of approximately 0.48 (higher or lower amounts of nanocomponents did not influence the improvement of the technological parameters of fresh and set cement slurries);

- $\quad$ samples containing $\mathrm{n}-\mathrm{SiO}_{2}$ had a very low (approximately $2 \%$ ) share of capillary pores, in which channels could be generated for the flow of reservoir fluids through the cement mantle of the borehole;

- pores with the smallest dimensions (below $100 \mathrm{~nm}$ ) constitute a vast majority (above $95 \%$ ) of the total number of pores present in the cement matrix of samples with n- $\mathrm{SiO}_{2}$, which evidences very low permeability for a reservoir medium;

- in temperatures from 40 to $60^{\circ} \mathrm{C}$, the thickening times of slurries with an addition of $\mathrm{n}-\mathrm{SiO}_{2}$ can be successfully adjusted by means of commonly available retardants;

- Slurries with $\mathrm{n}-\mathrm{SiO}_{2}$ achieved the value of early compressive strength (3.5 MPa) after times between approximately 8 and $14 \mathrm{~h}$. After this period, the cement stone is strong enough to enable the performance of further work in the borehole;

- after 28 days of hydration, the compressive strength of samples with $\mathrm{n}-\mathrm{SiO}_{2}$ took on high values. For samples with an addition of $0.5 \%$ of $n-\mathrm{SiO}_{2}$ they amounted to approximately $34-36 \mathrm{MPa}$, and with an addition of $1 \%$ of $\mathrm{n}-\mathrm{SiO}_{2}$-approximately $37-39 \mathrm{MPa}$;

- for slurries with $\mathrm{n}-\mathrm{Al}_{2} \mathrm{O}_{3}$ tested in a temperature of $60{ }^{\circ} \mathrm{C}$ based on class $\mathrm{G}$ drilling cement, very good technological parameters were achieved for samples containing $1 \%$ of $n-\mathrm{Al}_{2} \mathrm{O}_{3}$ and $3 \%$ of $\mathrm{n}-\mathrm{Al}_{2} \mathrm{O}_{3}$. The optimal water-cement ratio for such slurries amounted to approximately 0.44 , and the slurries had densities of approximately $1905-1920 \mathrm{~kg} / \mathrm{m}^{3}$;

- the most important advantage of slurries with $\mathrm{n}-\mathrm{Al}_{2} \mathrm{O}_{3}$ involved their high mechanical strength (after 28 days often exceeding $35 \mathrm{MPa}$ ), fast increase in early mechanical strength (quickly achieving a strength value of $3.5 \mathrm{MPa}$ ) and the creation of a compact microstructure with low porosity after setting;

- elevated (compared to the base slurry) values of compressive strength were also observed in slurries containing $\mathrm{n}-\mathrm{Al}_{2} \mathrm{O}_{3}$, resulting from the tight packing of nanoparticles with very small sizes in the cement matrix. The microstructure of slurries with nanosized alumina is uniform and characterised by low porosity, as indicated by photographs taken under a scanning microscope;

- for cement slurries containing an addition of multi-walled carbon nanotubes, the most preferable results were produced with water-cement ratios of 0.45 and 0.47 , and the slurries had densities of approximately $1860-1870 \mathrm{~kg} / \mathrm{m}^{3}$;

- the addition of carbon nanotubes caused an increase in the plastic viscosity of slurries,

- cement stones with an addition of MWCNTs are characterised by low porosities and a low share of macropores; pores with the smallest sizes (below $100 \mathrm{~nm}$ ) constitute over $97 \%$ of the total number of pores;

- an addition of $0.1 \%$ is an optimal amount of multi-walled carbon nanotubes; in the case of a higher amount, the resulting values of compressive strength were lower, 
- the addition of even a small amount of MWCNTs improves the strength parameters of cement stone by densifying its microstructure. For samples with an addition of $0.1 \%$ of MWCNTs, after 28 days of hydration the resulting compressive strength was as high as $50.5 \mathrm{MPa}$.

Author Contributions: Conceptualization, M.R. and M.K.; Formal analysis, M.R. and M.K.; Investigation, M.R. and M.K.; Methodology, M.R. and M.K.; Writing-original draft, M.R. and M.K. All authors have read and agreed to the published version of the manuscript.

Funding: This research was financially supported by Polish Ministry of Science and Higher Education within statutory funding for Oil and Gas Institute-National Research Institute.

Conflicts of Interest: The authors declare no conflict of interest.

\section{References}

1. Patil, R.; Deshpande, A. Use of Nanomaterials in Cementing Applications. In Proceedings of the SPE International Oilfield Nanotechnology Conference and Exhibition, Noordwijk, The Netherlands, 12-14 June 2012. [CrossRef]

2. Horszczaruk, E.; Mijowska, E.; Cendrowski, K.; Mijowska, S.; Sikora, P. Wpływ nanokrzemionki o zróżnicowanej morfologii na właściwości mechaniczne zapraw cementowych. Cem. Wapno Beton 2013, 1, 24-32.

3. De La Roij, R.; Egyed, C.; Lips, J.P. Nano-Engeneered Oil Well Cement Improves Flexibility and Increases Compressive Sterngth: A Laboratory Study. Soc. Pet. Eng. 2012. [CrossRef]

4. Kuilla, T.; Bhadra, S.; Yao, D.; Kim, N.H.; Bose, S.; Lee, J.H. Recent advances in graphene based polymer composites. Prog. Polym. Sci. 2010, 35, 1350-1375. [CrossRef]

5. Huang, X.; Qi, Y.; Boey, F.; Zhang, H. Graphene based composites. Chem. Soc. Rev. 2012, 41, 666-686. [CrossRef]

6. Nasibulin, A.G.; Koltsiva, T.; Nasibulin, L.I.; Anoshkin, I.V.; Semencha, A.; Tolochko, O.V.; Kauppinen, E.I. A novel approach to composite preparation by direct synthesis of carbon nanomaterial on matrix or filler particles. Acta Mater. 2013, 61, 1862-1871. [CrossRef]

7. Li, H.; Xiao, H.; Ou, J. Microstructure of Cement Mortar with Nano-Particles. Compos. Part B Eng. 2004, 35, 185-189. [CrossRef]

8. Li, Z.; Wang, H.; He, S.; Lu, Y.; Wang, M. Investigations on the preparation and mechanical properties of the nano-alumina reinforced cement composite. Mater. Lett. 2005, 60, 356-359. [CrossRef]

9. Nazari, A.; Riahi, S. Al2O3 nanoparticles in concrete and different curing media. Energy Build. 2011, 43, 1480-1488. [CrossRef]

10. Al-Saud, T.S.; Bin Hussain, M.A.A.; Batyanovskii, E.I.; Zhdanok, S.A.; Krauklis, A.V.; Samtsou, P.P. Influence of carbon nanomaterials on the properties of cement and concrete. J. Eng. Phys. Thermophys. 2011, 84, 546-553. [CrossRef]

11. Rahman, M.K.; Khan, W.A.; Mahmoud, M.A.; Sarmah, P. MWCNT for Enhancing Mechanical and Thixotropic Properties of Cement for HPHT Applications. Offshore Technol. Conf. 2016. [CrossRef]

12. Rahman, M.K.; Murtaza, M. Effect of Nanoclay on Mechanical and Rheological Properties of Oil well Cement Slurry under HPHT Environment. Int. Pet. Technol. Conf. 2015. [CrossRef]

13. Wilk, K.; Kasza, P.; Czupski, M. Zastosowanie nanocieczy jako dodatków wspomagajacych proces wypierania ropy naftowej. Nafta-Gaz 2014, 1, 14-20.

14. Leon, N.; Massana, J.; Alonso, F.; Moragues, A.; Sanchez-Espinosa, A. Effect of Nano-Si2O and Nano-Al2O3 on Cement Mortars for Use in Agriculture and Livestock Production. Available online: www.elsevier.com/ locate/issn/15375110 (accessed on 24 January 2019).

15. Dębińska, E.; Rzepka, M.; Kremieniewski, M. Nanocząsteczki-nowa droga w kształtowaniu parametrów świeżych i stwardniałych zaczynów cementowych. Nafta-Gaz 2016, 12, 1084-1091. [CrossRef]

16. Dębińska, E. Niekonwencjonalne zaczyny cementowe z dodatkiem nanokrzemionki. Nafta-Gaz 2016, 5, 290-300.

17. Ershadi, V.; Ebadi, T. The Effect of Nanosilica on Cement Matrix Permeability in Oil Well to Decrease the Pollution of Receptive Environment. Int. J. Enviromental Sci. Dev. 2011, 2, 128-132. [CrossRef] 
18. Dębińska, E. Wpływ nanokrzemionki na parametry mechaniczne kamienia cementowego. Nafta-Gaz 2014, 4, 229-235.

19. Biricik, I.H.; Sarier, N. Comparative study of the characteristics of nano silica-, silica fume-and fly ash-incorporated cement mortars. Mater. Res. 2014, 17, 570-582. [CrossRef]

20. Musso, S.; Tulliani, J.-M.; Ferro, G.; Tagliaferro, A. Influence of carbon nanotubes structure on the mechanical behavior of cement composites. Compos. Sci. Technol. 2009, 69, 1985-1990. [CrossRef]

21. Kosta-Gdoutos, M.S.; Metaxa, Z.S.; Shah, S.P. Multi-scale mechanical and fracture characteristics and early-age strain capacity of high performance carbon nanotube/cement nanocomposites. Cem. Concr. Compos. 2010, 32, 110-115. [CrossRef]

22. Chuah, S.; Pan, Z.; Sanjayan, J.G.; Wang, C.M.; Duan, W.H. Nano reinforced cement and concrete composites and new perspective from graphene oxide. Constr. Build. Mater. 2014, 73, 113-124. [CrossRef]

23. Hu, Y.; Luo, D.; Li, P.; Li, Q.; Sun, G. Fracture toughness enhancement of cement paste with multi-walled carbon nanotubes. Constr. Build. Mater. 2014, 70, 332-338. [CrossRef]

24. Luo, J.; Duan, Z.; Li, H. The influence of surfactants on the processing of multi-walled carbon nanotubes in reinforced cement matrix composites. Phys. Status Solidi 2009, 206, 2783-2790. [CrossRef]

25. Hielscher, T. Ultrasonic Production of Nano-Size Dispersions and Emulsions. In Proceedings of the European Nanosystems Conference, ENS'05, Paris, France, 14-16 December 2005; pp. 138-143.

26. Hadi, H.A.; Ameer, H.A. Experimental Investigation of Nano Alumina and Nano Silica on Strength and Consistency of Oil Well Cement. J. Eng. 2017, 23, 51-69.

27. Fernandes de Morais, J.; Naked Haddad, A. Analysis by ultrasound of the behavior of carbon nanotubes on cementitious composites. J. Nanotechnol. Adv. Mater. 2014, 2, 89-98. [CrossRef]

28. Li, X.; Rafieepour, S.; Miska, S.Z.; Takach, N.E.; Ozbayoglu, E.; Tu, M.; Mata, C. Carbon nanotubes reinforced lightweight cement testing under tri-axial loading conditions. J. Pet. Sci. Eng. 2019, 174, 663-675. [CrossRef]

29. Campillo, I.; Dolado, J.S.; Porro, A. High-performance nanostructured materials for construction. In Proceedings of the 1st International Symposium on Nanotechnology in Construction, The Royal Society of Chemistry, Paisley, Scotland, 23-25 June 2003; pp. 215-226.

30. Wang, B.; Han, Y.; Liu, S. Effect of highly dispersed carbon nanotubes on the flexural toughness of cement-based composites. Constr. Build. Mater. 2013, 46, 8-12. [CrossRef]

31. Chaipanich, A.; Nochaiya, T.; Wongkeo, W.; Torkittikul, P. Compressive strength and microstructure of carbon nanotubes-fly ash cement composites. Mater. Sci. Eng. 2010, 527, 1063-1067. [CrossRef]

32. Li, G.Y.; Wang, P.M.; Zhao, X. Mechanical behavior and microstructure of cement composites incorporating surface-treated multi-walled carbon nanotubes. Carbon 2005, 43, 1239-1245. [CrossRef]

33. Li, G.Y.; Wang, P.M.; Zhao, X. Pressure-sensitive properties and microstructure of carbon nanotube reinforced cement composites. Cem. Concr. Compos. 2007, 29, 377-382. [CrossRef]

34. Cwirzen, A.; Habermehl-Cwirzen, K.; Nasibulin, A.; Kaupinen, E.; Mudimela, P.; Penttala, V. SEM/AFM studies of cementitious binder modified by MWCNT and nano-sized Fe needles. Mater. Charact. 2009, 60, 735-740. [CrossRef]

35. El-Gamal, S.M.A.; Hashem, F.S.; Amin, M.S. Influence of carbon nanotubes, nanosilica and nanometakaolin on some morphological-mechanical properties of oil well cement pastes subjected to elevated water curing temperature and regular room air curing temperature. Constr. Build. Mater. 2017, 146, 531-546. [CrossRef]

36. De Paula, J.N.; Calixto, J.M.; Ladeira, L.O.; Ludvig, P.; Souza, T.C.C. Tensile Strength of Oil-Well Cement Pastes Produced with Carbon Nanotubes Directly Synthesized on Clinker. Int. J. Eng. Sci. 2018, 7, 57-62. [CrossRef]

37. De Paula, J.N.; Calixto, J.M.; Ladeira, L.O.; Ludvig, P.; Souza, T.C.C.; Rocha, J.M.; Vargas de Melo, A.A. Mechanical and rheological behavior of oil-well cement slurries produced with clinker containing carbon nanotubes. J. Pet. Sci. Eng. 2014, 122, 274-279. [CrossRef]

38. Collins, F.; Lambert, J.; Duan, W.H. The influence of admixtures on the dispersion, workability, and strength of carbon nanotube-OPC paste mixtures. Cem. Concr. Compos. 2014, 34, 201-207. [CrossRef]

39. Ghajari, A.; Gholinezhad, J.; Soltanian, H.; Alireza Mortazavi, S. An improvement to physical properties of heavy-weight oil well cements using carbon nanotubes. J. Pet. Sci. Technol. 2014, 4, 10-19. [CrossRef]

40. Santra, A.; Boul, P.J.; Pang, X. Influence of Nanomaterials in Oilwell Cement Hydration and Mechanical Properties. SPE Int. Oilfield Nanotechnol. Conf. Exhib. 2012. [CrossRef] 
41. Mondal, P.; Shah, S.P.; Marks, L.D.; Gaitero, J.J. Comparative Study of the Effects of Microsilica and Nanosilica in Concrete. Transp. Res. Rec. J. Transp. Res. Board 2010, 2141, 6-9. [CrossRef]

42. Rzepka, M.; Kremieniewski, M.; Kedzierski, M. Cement slurries for sealing casing in boreholes with increased risk of gas migration. Nafta-Gaz 2019. [CrossRef]

43. Rzepka, M.; Kędzierski, M. Zaczyny cementowe z dodatkiem nanokomponentów do uszczelniania kolumn rur okładzinowych w otworach wiertniczych o głębokości końcowej około 1000-2000 metrów. Nafta-Gaz 2019, 11. [CrossRef]

44. Katalog GetNanoMaterials. Available online: https://www.getnanomaterials.com/nanoparticles/silica/sio2121-1-um-amorphous-spherical/ (accessed on 25 February 2020).

45. Katalog GetNanoMaterials. Available online: https://www.getnanomaterials.com/al-0138hw-40-50-nm/ (accessed on 25 February 2020).

46. Katalog ACS Material. Available online: https://www.acsmaterial.com/carbon-nanotubes-multi-walled-nh2functionalized-mwcnts.html (accessed on 18 February 2020).

47. PN-EN ISO 10426-1:2009 Przemyst Naftowy i Gazowniczy-Cementy i Materiały do Cementowania Otworów-Część 1: Specyfikacja; The Polish Committee for Standardization: Warsaw, Poland, 2009.

48. PN-EN ISO 10426-2:2003 Przemyst Naftowy i Gazowniczy-Cementy i Materiaty do Cementowania Otworów Wiertniczych-Część 2: Badania Cementów Wiertniczych; The Polish Committee for Standardization: Warsaw, Poland, 2003.

(C) 2020 by the authors. Licensee MDPI, Basel, Switzerland. This article is an open access article distributed under the terms and conditions of the Creative Commons Attribution (CC BY) license (http://creativecommons.org/licenses/by/4.0/). 